Military Communities and Temple Patronage: A Case Study of Britain and Pannonia Author(s): David Walsh

Source: American Journal of Archaeology, Vol. 124, No. 2 (April 2020), pp. 275-99

Published by: Archaeological Institute of America

Stable URL: https://www.jstor.org/stable/10.3764/aja.124.2.0275

JSTOR is a not-for-profit service that helps scholars, researchers, and students discover, use, and build upon a wide range of content in a trusted digital archive. We use information technology and tools to increase productivity and facilitate new forms of scholarship. For more information about JSTOR, please contact support@jstor.org.

Your use of the JSTOR archive indicates your acceptance of the Terms \& Conditions of Use, available at https://about.jstor.org/terms 


\title{
Military Communities and Temple Patronage: A Case Study of Britain and Pannonia
}

\author{
DAVID WALSH
}

Much has been written on the religious aspects of life in the Roman military community, but the role of soldiers as temple patrons has rarely been discussed, even though temples and shrines have been found at military settlements across the Roman empire and many temples situated in urban areas have produced evidence of financial support from soldiers. Thus, exploring the relationship between military communities and temples is important for our understanding of the religious dimension of these communities and, moreover, of wider developments in temple-based worship in the Roman empire. Indeed, the emperors of the late third century CE came from this social milieu, and their disposition toward temples would have been affected by their experiences during military service. I demonstrate here how and why support for temple construction, repair, and expansion among the military communities in two of the most militarized provinces, Britain and Pannonia, decreased dramatically after the early third century and why certain temples (Mithraea and Dolichena) did not similarly decline. This examination also reveals how the changing relationship between military communities and temples influenced the attitudes of late third-century emperors toward temple construction and repair. ${ }^{1}$

\section{INTRODUCTION}

When discussing the declining status of temples in the Roman world, scholarly works have traditionally looked to the fourth century, during which Christianity progressed from the favored religion of the emperor Constantine I (d. $337 \mathrm{CE}$ ) to the official religion of the empire under Theodosius I (d. $395 \mathrm{CE}) .^{2}$ During this period, laws were issued that prohibited pagan practices and ultimately required the closure of temples, and various texts describe assaults on temples by Christian monks and bishops. ${ }^{3}$ However, recent decades have seen a substantial shift in our understanding of how patterns of temple construction and repair differed through the course of the Roman period, and it is evident that investment in such structures had begun to decline long before the fourth century. ${ }^{4}$ It would be misleading to presume

American Journal of Archaeology Volume 124, Number 2

April 2020

Pages 275-99

DOI: $10.3764 /$ aja.124.2.0275

www.ajaonline.org

\footnotetext{
${ }^{1}$ Many thanks to those who have read and commented on the manuscript of this article, including Ellen Swift, Michael Mulryan, and Mark Crittenden, as well as the editors of the $A J A$ and the three anonymous reviewers for the journal. Thanks also go to Lloyd Bosworth for helping create the distribution maps. Figures are my own unless otherwise noted.

${ }^{2}$ Lavan 2011, xxii-xxiii.

${ }^{3}$ For anti-temple legislation, see Cod. Theod. 16.10.4 (346/54/56 CE) and 16.10.24 (435 CE). Examples of attacks on temples by Christians recorded in the literary texts include the Alexandrian Serapeum: Rufinus, Hist. eccl. 11.22-23; a Mithraeum in Alexandria: Socrates, Hist.eccl.3.2; a Mithraeum in Rome: Jer., Ep. 107.2; Gaza: Mark the Deacon, Vita S. Porphyrii 65-66; Atripe in Egypt: Besa, Vita Sinuthii 84; Gaul: Sulpicius Severus, Vita S. Martin 13-15, Dialogi 3.8.

${ }^{4}$ See Lavan and Mulryan 2011 for chapters on the decline of temple building in Egypt, Gaul, North Africa, and Spain. On Italy, see Jouffroy 1986, 326.
} 
that this decline was uniform across temple types, locations, or the community served. A range of factors could have led an individual or group to finance the construction or repair of a temple-or alternatively to neglect their duty to do so-and these factors could have varied considerably depending on the context. For example, in order to join the local town council, one was obliged to fund the construction and repair of public buildings, often including temples, for the benefit of the community. This wealth requirement meant that membership of town councils was only open to a select few in Roman society, yet, from the third century CE on, serving as a town councillor became less attractive as a career path, and there is a consequent decline in euergetism. However, this rejection of a method for social advancement by the wealthy cannot account for diminishing support for temples among other social groups. ${ }^{5}$

One group that has received almost no attention regarding its role in temple patronage, at least beyond discussions of individual sites, is the military community. That the role of individuals and groups from this social milieu has not been considered in the construction and repair of temples is striking for several reasons. First, religion was a major aspect of life in the military community. ${ }^{6}$ This was especially true for soldiers, for whom official festivals and rituals created a sense of uniformity across a wide geographical area. At the same time, participation in nonofficial cults could serve either to integrate soldiers into their local context or to help them retain aspects of their identity that were linked to their place of origin. ${ }^{7}$ Second, soldiers are often presented as the foremost agents in the spread of Roman culture, ${ }^{8}$ which in the northwest provinces included the construction of structures to house religious practices. Finally, beginning in the mid third century CE, the status of particular cults and temples among the army would have significantly affected the attitude of the imperial court toward certain religious institutions, for it was from the armies that emperors

\footnotetext{
${ }^{5}$ Ward-Perkins 1984, 15-17.

${ }^{6}$ Studies on the role of religion in the military community include ANRW 2.16.1:1470-505; 1506-541; 1542-555; Haynes 1997; Irby-Massie 1999; Wolff 2009.

${ }^{7}$ Mattingly 2006, 214-20.

${ }^{8}$ James 1999, 24.
}

arose, and these emperors relied on their popularity with the armies to keep themselves in power.

In this article, I demonstrate how investment in the construction and repair of temples associated with the military community in Britain and Pannonia changed from the end of the first century CE to the early fourth century. Evidence provided here shows that, in both provinces, there was a drastic reduction in financial support for temples connected to the military community during the third to early fourth centuries and that the possible factors leading to this decline consist of: the absence of direct imperial stimulus following the Severan period; the difficulty faced by soldiers in supporting such projects when garrisons were reduced in size or the soldiers' relative pay decreased; the changing nature of euergetism in Roman society; and the trend away from using temples to demonstrate a relationship with the divine in a military environment. Finally, the article explores why temples dedicated to Mithras and Jupiter Dolichenus (commonly referred to as Mithraea and Dolichena) continued to be built and repaired, and how their continuing popularity led to the Tetrarchs' unprecedented decision to fund the repair of a Mithraeum at Carnuntum.

Britain and Pannonia (both Superior and Inferior) serve well as case studies because these two regions played host to a far greater military presence than many other provinces, particularly those in the interior of the Roman empire. Between $10 \%$ and $12 \%$ of the Roman military was stationed in Britain, although the province constituted only $4 \%$ of the empire's territory, and four legions as well as many auxiliary units were stationed in Pannonia. ${ }^{9}$ Both provinces have also produced considerably large corpora of materials relating to temples at military sites. In the case of Pannonia, the majority of this evidence takes the form of inscriptions, while for Britain, scholars are much more reliant on architectural evidence. Unfortunately, in both areas, the inscriptions rarely specify what type of building work took place and generally only indicate that the work was an initial construction or a rebuilding, and many inscriptions are in a fragmentary condition. This study includes all the temples and shrines within forts and in the surrounding settlements (vici) for which there is evidence from archaeological excavations or in the epigraphic record.

\footnotetext{
${ }^{9}$ Holder 2003, 145; Mattingly 2006, 166.
} 
Some, such as Aquincum and Carnuntum, have both vici and nearby towns. However, despite their close proximity to forts, temples are only included here from these towns if they have produced evidence of a direct link to the military. In addition, the study includes all instances in which surviving dedications indicate that temples in both civilian towns (e.g., the Mithraea in London and Poetovio) and rural settings (e.g., the shrines at Scargill Moor) exhibit a strong relationship with the military; however, it does not include the shrine of the standards, which was located in every fort headquarters (principia), as this was an official part of a camp's layout.

\section{TEMPLES IN BRITAIN}

From the period of Nerva's reign to the death of Hadrian (96-138 CE), when there was a settled military presence in Britain, there are several extant examples of temples and shrines supported by the military (figs. 1, 2). These include the Romano-Celtic temple at Vindolanda; two shrines (one rectangular and the other circular) at Scargill Moor that contained, respectively, dedications from a centurion and a prefect of the First Cohort of Thracians; and a shrine to the Matres (Mother Goddesses) that was erected at Winchester by an officer in the service of the provincial governor (beneficiarius consularis) (fig. 3$).{ }^{10}$ In the following decades (138-192 CE), an increasing number of temples and shrines are attested archaeologically and epigraphically, particularly in the north of Britain, where an extensive military presence was stationed following the construction of Hadrian's and Antoninus' walls (fig. 4). Religious structures from this period include a small apsidal temple to Antenociticus at Benwell, Coventina's Well at Carrawburgh, a circular temple and a temple with a portico on a rectangular podium at Maryport, and a Mithraeum at Inveresk. Inscriptions attesting to religious buildings have been found at Brough-on-Noe (to Hercules Augustus), Caerleon (to Jupiter and the imperial cult), South Shields (to

\footnotetext{
${ }^{10}$ Vindolanda: Blake 2003, 1. Scargill Moor: Richmond and Wright 1948, 110. Winchester: Collingwood and Wright 1965, no. 88, with translation: "Matrib(us) | Italis Ger|manis | Gal(lis) Brit(annis) || [A]ntonius | [Lu]cretianus | [b(ene)]f(iciarius) co(n)s(ularis) rest(ituit)" (To the Italian, German, Gallic, and British Mother Goddesses Antonius Lucretianus, beneficiarius consularis, restored [this]).
}

the imperial cult), and Corbridge (to Sol Invictus; fig. 5). ${ }^{11}$ It was in the Severan period (193-235 CE) that construction work on temples and shrines relating to military communities reached its apogee (fig. 6). At least five Mithraea were constructed - at Caernarvon, Carrawburgh, High Rochester, Housesteads, and Rudchester - and a Dolichenum was repaired at Old Penrith by a prefect. ${ }^{12}$ Dolichena were also built at Piercebridge and Vindolanda, with the latter situated just inside the north wall of the fort. ${ }^{13}$ The location of the Vindolanda Dolichenum is highly unusual, for extant temples situated inside forts are extremely rare across the entire empire. The only other definite instance is the Mithraeum uncovered inside the tribune's residence within the fort at Aquincum in Pannonia. ${ }^{14}$ However, as Birley and Birley have observed, it is possible that an earlier Dolichenum was located outside the Vindolanda fort. ${ }^{15}$ Temples were also restored at Netherby by the First Aelian Cohort of Spaniards (fig. 7) ${ }^{16}$ and at Ribchester by a centurion

\footnotetext{
${ }^{11}$ Benwell: Simpson and Richmond 1941, 39. Coventina's Well: Allason-Jones and McKay 1985, 11-12. Maryport: Lewis 1966, 86, 106. Inveresk: Hunter et al. 2016, 125. Brough-onNoe: Collingwood and Wright 1965, no. 318. Caerleon: Tomlin et al. 2009, no. 3079. South Shields: Collingwood and Wright 1965, no. 1056. Irby-Massie 1999, no. 10. Corbridge: Collingwood and Wright 1965, no. 1137, with translation: "[ [Soli Invicto]] | vexillatio | leg(ionis) VIVic(tricis) P(iae) F(idelis) f(ecit) | sub cura Sex(ti) || Calpurni Agrico|lae leg(ati) Aug(usti) pr(o) pr(aetore)" (To the Invincible Sun-god a detachment of the Sixth Legion Victrix Pia Fidelis set this up under the charge of Sextus Calpurnius Agricola, emperor's propraetorian legate).

${ }^{12}$ Caernarvon: Boon 1960, 144. Carrawburgh: Walsh 2018a, 103. High Rochester: Vermaseren 1956-1960, 1: no. 876. Housesteads: Walsh 2018a, 102. Rudchester: Gillam and MacIvor 1954, 217, 218. Old Penrith: Collingwood and Wright 1965, no. 916; Irby-Massie 1999, no. 399.

${ }^{13}$ Piercebridge: Cool and Mason 2008, 104. Vindolanda: Birley and Birley 2012, 231.

${ }^{14}$ Póczy 1986, 215.

${ }^{15}$ Birley and Birley 2012, 232-34.

${ }^{16}$ Collingwood and Wright 1965, no. 979, with translation: “[...] is coh(ors) [I Ael(ia) Hisp(anorum) q(uitata)] | [[[Se] veriana [Alexandriana]]] | templum nu[per nimia vetus]|tate conlabsu[m restituit et $]||$ ad pristinam [formam consum]|mavit imp(eratoribus) d(ominis) [n(ostris)...] | [...]” (... the First Aelian Cohort of Spaniards, one thousand strong, part-mounted, Severiana Alexandriana, restored this temple, lately fallen in through excessive age, and completed it according to its previous pattern when the Emperors our Lords ... [were consuls]).
} 


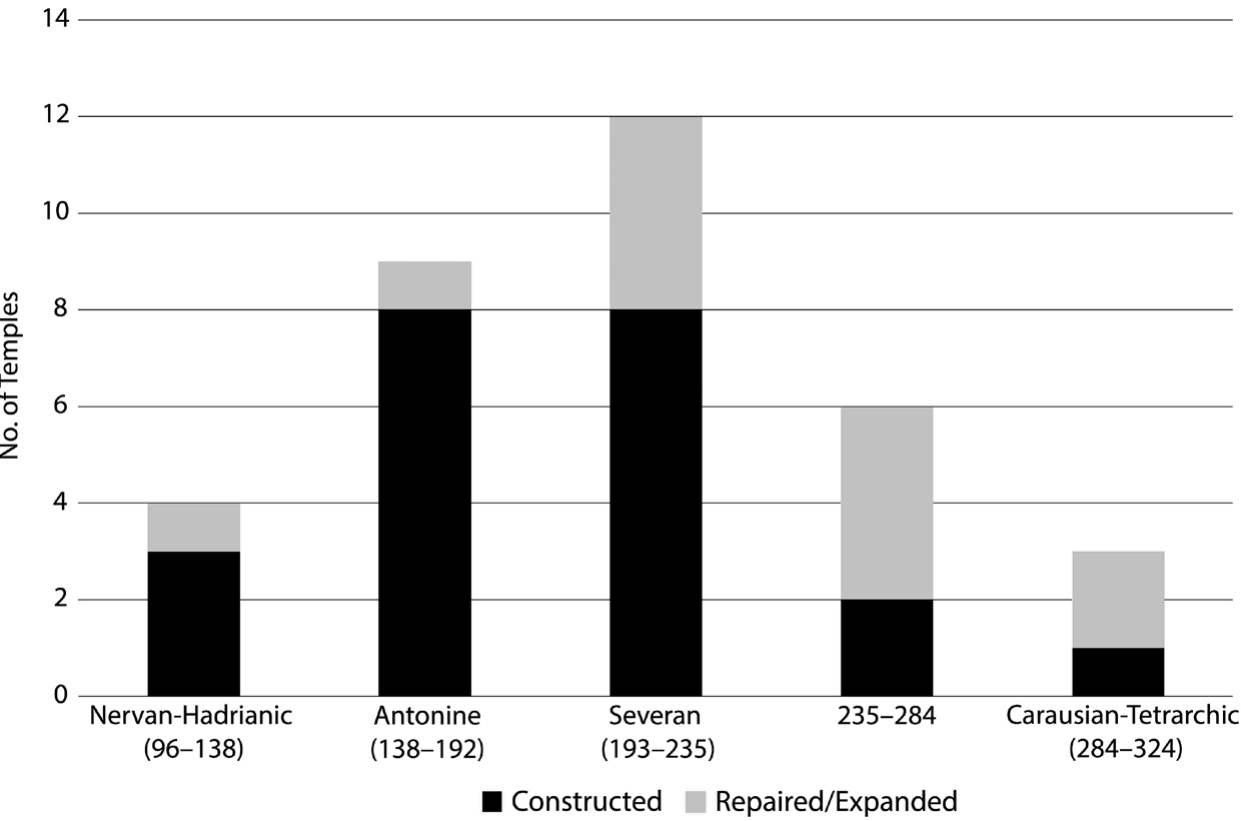

FIG. 1. Construction and repair or expansion of temples associated with the military in Britain.

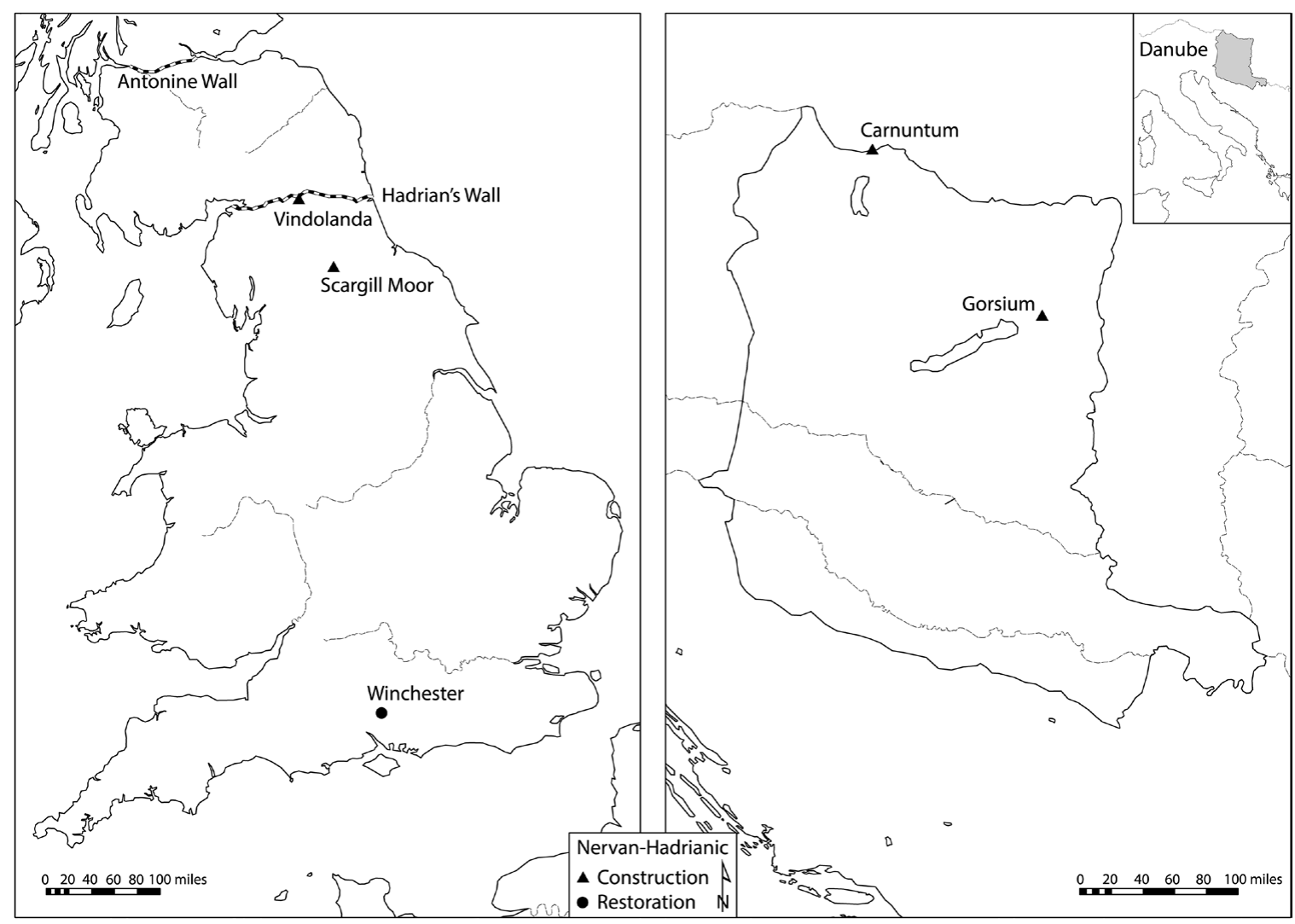

FIG. 2. Distribution of temple construction and repair or expansion in the Nervan-Hadrianic period (96-138 CE) in Britain (left) and Pannonia (right). 


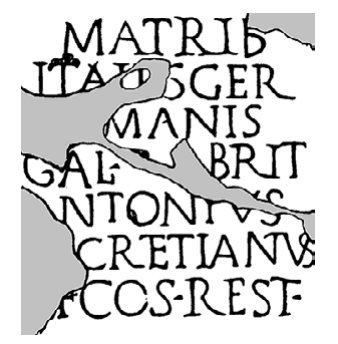

FIG. 3. Inscription on an altar dedicated to the Mother Goddesses from Winchester, sandstone altar, late first to early second century CE, ht. ca. $0.3 \mathrm{~m}$. London, British Museum, inv. no. 1856,701.5025 (modified from Vanderbilt 2017, no. 88).

(fig. 8). ${ }^{17}$ According to extant inscriptions, the legate (commander of a legion) Claudius Hieronymianus built a temple to Serapis at York, while another legate restored a temple to Isis in London. ${ }^{18}$

A number of things are apparent from the evidence outlined thus far. First, the increasing evidence for investment in temples by soldiers remained largely confined to areas in which the military was stationed. This suggests that soldiers had little desire to advertise this benefaction to the civilian communities in the urban centers of the south but rather wished to focus their efforts on their immediate surroundings, seeking, one presumes, to make a statement to their comrades and superiors. To do so, however, one did not necessarily need to fund a gigantic structure, for the temples and shrines discussed thus far are rarely of considerable size, most covering less than $100 \mathrm{~m}^{2}$ (table 1 ). In some cases, such as Mithraea or Dolichena, which account

\footnotetext{
${ }^{17}$ Collingwood and Wright 1965 , no. 587, with translation: "[...p]ro | [sa]1(ute) im $[\mathrm{p}$ (eratoris) Caes(aris)] [[[Al] ex[andri $]]$ | [Aug(usti) N(ostri) et $]$ | [Iul(iae) Mamaeae ma $] \mathrm{t}[\mathrm{r}]$ is $\mathrm{D}$ (omini) $\mathrm{N}$ (ostri) et | castr(orum) su[b cura] || Val(eri) Crescentis Fulviani leg(ati) eius $\mid \operatorname{pr}[$ o prae(tore)] $\mathrm{T}$ (itus) Florid(ius) Natalis leg(ionis) praep(ositus) $\mid \mathrm{n}$ (umeri) et regi[onis] | templum a solo ex responsu [dei re]|stituit et dedicavit d[e suo]" (To ... for the welfare of our Emperor Caesar Alexander Augustus and of Julia Mamaea the mother of our Lord (the Emperor) and of the army, under the charge of Valerius Crescens Fulvianus, his pro-praetorian governor, Titus Floridius Natalis, legionary centurion and commandant of the unit and of the region, restored from ground-level and dedicated this temple from his own resources according to the reply of the $\operatorname{god} . .$.$) .$

${ }^{18}$ York: Collingwood and Wright 1965, no. 658. London: Tomlin et al. 2009, no. 3001 .
}

for most of the extant temple structures, one would expect these temples to be small in size following the trend across the empire, yet even the porticoed temple at Maryport covered only just over $100 \mathrm{~m}^{2} .{ }^{19}$ Consequently, while there was an increasing desire in military communities to invest in temples, this did not lead to the construction of larger temples. Second, the epigraphic evidence suggests that soldiers of all ranks desired to invest in temples, from the First Aelian Cohort of Spaniards paying as a unit, to centurions, prefects, and legates. Often, the recipient of these dedications was the emperor, and occasionally the emperor's family, indicating that the construction or restoration of a religious structure was designed to demonstrate not only a soldier's piety or devotion to his local community but also his loyalty to the emperor. Third, from the mid second into the early third century, there was a notable growth in initiatory cults, particularly those of Jupiter Dolichenus and Mithras.

After the Severan period, there is a notable decline in the numbers of temples and shrines being built and restored. Indeed, there is no extant evidence for a temple or shrine built at a military site in Britain in the period between the death of Alexander Severus and the accession of Diocletian (235-284 CE; fig. 9). The only new temple connected to the military was the London Mithraeum, which contained an image of Mithras slaying the cosmic bull (the central image of the cult) funded by a veteran of the legio II Augusta (fig. 10) ${ }^{20} \mathrm{It}$ is speculative to say, but such a prominent dedication suggests that the veteran may have been responsible for the construction of the temple itself. ${ }^{21}$ There were, however, a number of temples repaired at military sites, two of which were Mithraea (Carrawburgh and Rudchester), along with the Vindolanda Dolichenum. In $238 \mathrm{CE}$, only three years after the death of Alexander Severus, a prefect named Agrippa restored a temple at Benwell in honor of "the Mother Goddesses of the Parade-ground and to the Genius of the First Cavalry

\footnotetext{
${ }^{19}$ For the sizes of Mithraea, see various entries in Vermaseren (1956-1960), and for Dolichena, see Schwarzer $(2012,190)$.

${ }^{20}$ Collingwood and Wright 1965, no. 3, with translation: "Ulpi|us | Silva|nus | (miles) fac|tus | Arau|sione | emeri|tus leg(ionis) | II Aug(ustae) | votum | solvit” (Ulpius Silvanus, emeritus of the Second Legion Augusta, paid his vow; enlisted at Orange).

${ }^{21}$ Walsh 2018a, 104.
} 


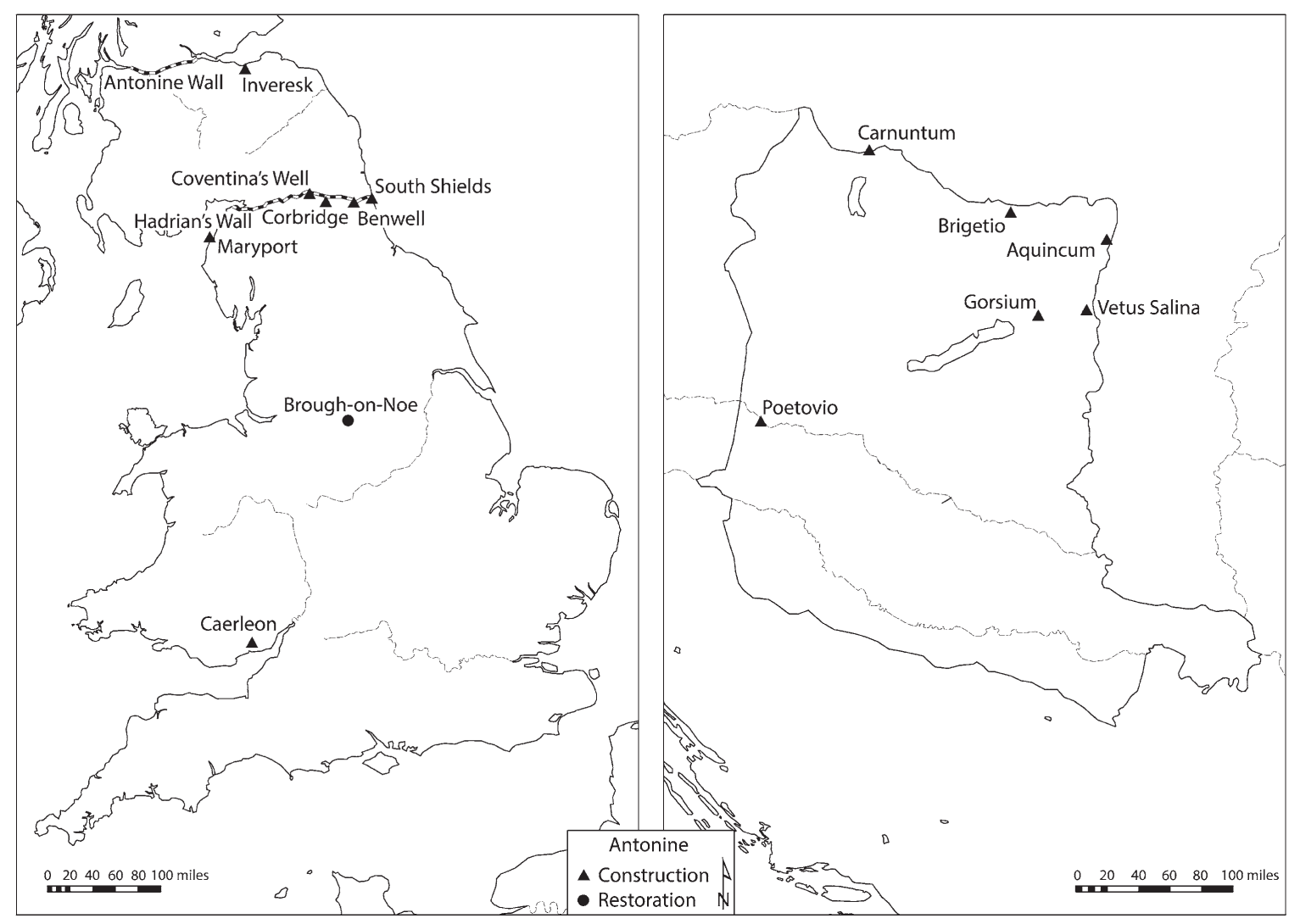

FIG. 4. Distribution of temple construction and repair or expanasion in the Antonine period (138-192 CE) in Britain (left) and Pannonia (right).

Regiment of Asturian Spaniards" (fig. 11). ${ }^{22}$ Under Carausius, Allectus, and then the Tetrarchy, the picture remains much the same (fig. 12). Just one new temple was built at a military site, a Dolichenum at Chesters, while only Mithraea exhibit evidence of restoration (at Carrawburgh and Caernarvon). ${ }^{23}$ Thereafter, during the reign of Constantius II in the mid fourth century (337-361 CE), the Vindolanda Dolichenum underwent further modification. ${ }^{24}$ There is no subsequent

${ }^{22}$ Carrawburgh: Walsh 2018a, 103. Rudchester: Gillam and MacIvor 1954, 218. Vindolanda: Birley and Birley 2012, 23637. Benwell: Collingwood and Wright 1965, no. 1334, with translation: "Matri\{ri\}bus Campes[t]r[i]b(us) | et Genio alae pri(mae) Hispano|rum Asturum [...] | [...] Gordi[a]nae T(itus) [...] Agrippa prae(fectus) templum a so(lo) res|tituit" (To the Mother Goddesses of the Parade-ground and to the Genius of the First Cavalry Regiment of Asturian Spaniards styled ... Gordian's Own Titus ... Agrippa, prefect, restored this temple from ground-level).

${ }^{23}$ Chesters: Tomlin et al. 2009, no. 3299. Carrawburgh: Walsh 2018a, 103. Caernarvon: Boon 1960, 153.

${ }^{24}$ Birley and Birley 2012, 237, 238.

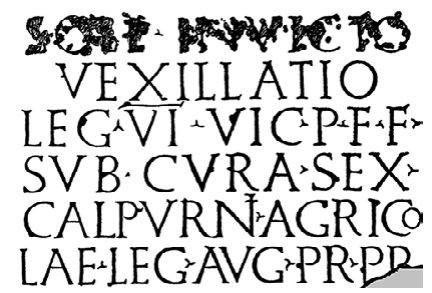

FIG. 5. Dedication to the Invincible Sun-god from Corbridge, sandstone dedicatory slab, 162-169 CE, ht. ca. $0.7 \mathrm{~m}$. Corbridge, Corbridge Museum, inv. no. 23325 (modified from Vanderbilt 2017, no. 1137).

evidence for the construction or repair of temples associated with the Roman military in Britain.

This rapid decline in temple building associated with the military community cannot be explained as the result of there being enough temples already present at military sites. Various extant temples discussed above were no longer in use by the beginning of the fourth century. ${ }^{25}$ The frequent reuse of altars at

\footnotetext{
${ }^{25}$ Benwell: Simpson and Richmond 1941, 39. Piercebridge: Cool and Mason 2008, 104. Maryport circular temple: Lewis
} 


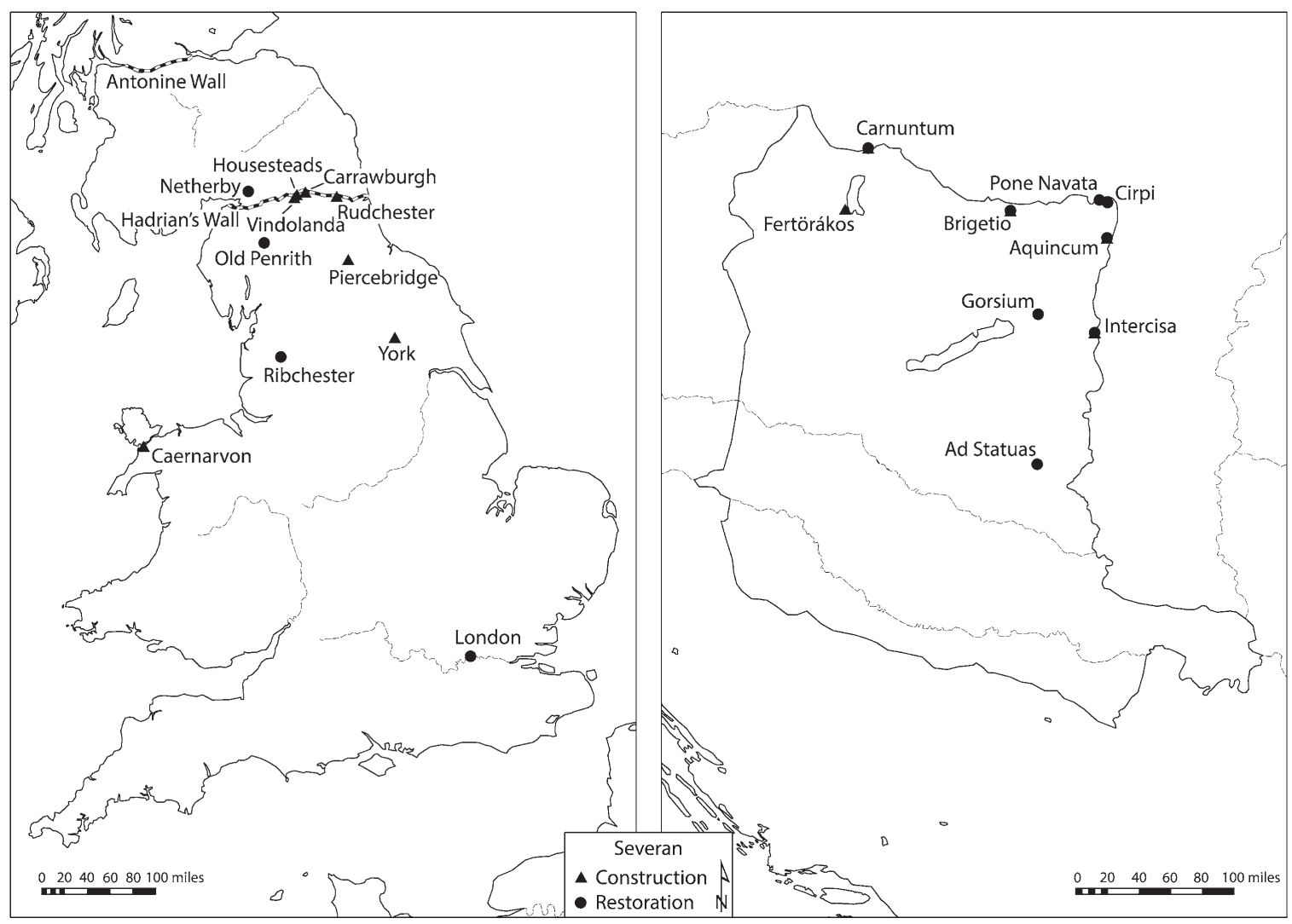

FIG. 6. Distribution of temple construction and repair or expansion in the Severan period (193-235 CE) in Britain (left) and Pannonia (right).

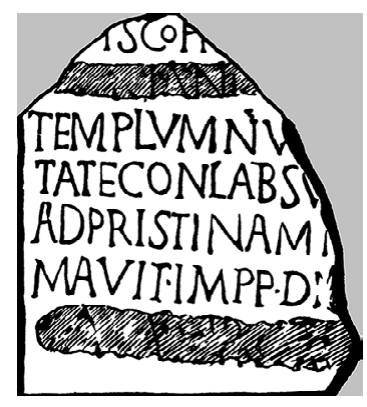

FIG. 7. Temple dedication by the First Aelian Cohort of Spaniards from Netherby, sandstone dedicatory slab, 222 CE, ht. 0.4 m. Carlisle, Tullie House Museum, inv. no. 1889.130.1892.15 (modified from Vanderbilt 2017, no. 979).

several sites in the fourth century also hints at temples being mined for spolia. At Lympe, an altar to Neptune was found among the building material of the late

1966, 86. Maryport classical porticoed temple: Lewis 1966 , 106. Richborough: T. Wilmott, pers. comm. 24 August 2018. Rudchester Mithraeum: Gillam and MacIvor 1954, 218. Vindolanda Romano-Celtic temple: Blake 2003, 11.

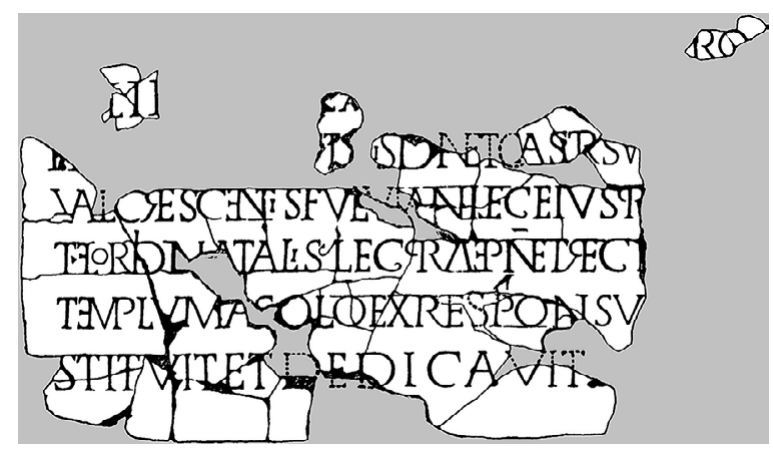

FIG. 8. Temple restoration dedication by a legionary centurion from Ribchester, stone dedicatory slab, 225-235 CE, ht. 0.7 $\mathrm{m}$. Ribchester, Ribchester Museum (modified from Vanderbilt 2017, no. 587).

third-century shore fort, ${ }^{26}$ and, farther north, altars have been found reused as building material in the fourth century at a number of sites, including Bewcastle, Carrawburgh, Ribchester, South Shields, and

\footnotetext{
${ }^{26}$ Collingwood and Wright 1965, no. 66.
} 
TABLE 1. Sizes of extant temples associated with the military in Britain.

\begin{tabular}{lcl}
\hline Location and Structure & Size $\left(\sim \mathrm{m}^{2}\right)$ & \multicolumn{1}{c}{ Reference } \\
\hline London, Mithraeum & 181 & Bryan et al. 2017, 103 \\
Rudchester, Mithraeum & 144 & Vermaseren 1956-1960, 1: no. 838 \\
Maryport, classical temple & 109 & Breeze 2018, 63 \\
Piercebridge, Dolichenum & 101 & Cool and Mason 2008, 81 \\
Maryport, circular temple & 85 & Haynes and Wilmott 2012, 27 \\
Vindolanda, Dolichenum & 80 & Birley and Birley 2012, 234 \\
Housesteads, Mithraeum & 77 & Vermaseren 1956-1960, 1: no. 852 \\
Caernarvon, Mithraeum & 69 & Vermaseren 1956-1960, 1: no. 2374 \\
Carrawburgh, Mithraeum & 44 & Vermaseren 1956-1960, 1: no. 844 \\
Benwell, Antenociticus temple & 35 & Lewis 1966, 72 \\
Inveresk, Mithraeum & 32 & Hunter et al. 2016, 159 \\
Scargill Moor, Vinotonus shrine & 20 & Richmond and Wright 1948, 107 \\
Vindolanda, Romano-Celtic temple & 18 & Birley 2009, 42 \\
Scargill Moor, Vinotonus Silvanus shrine & 16 & Richmond and Wright 1948, 109 \\
\hline
\end{tabular}

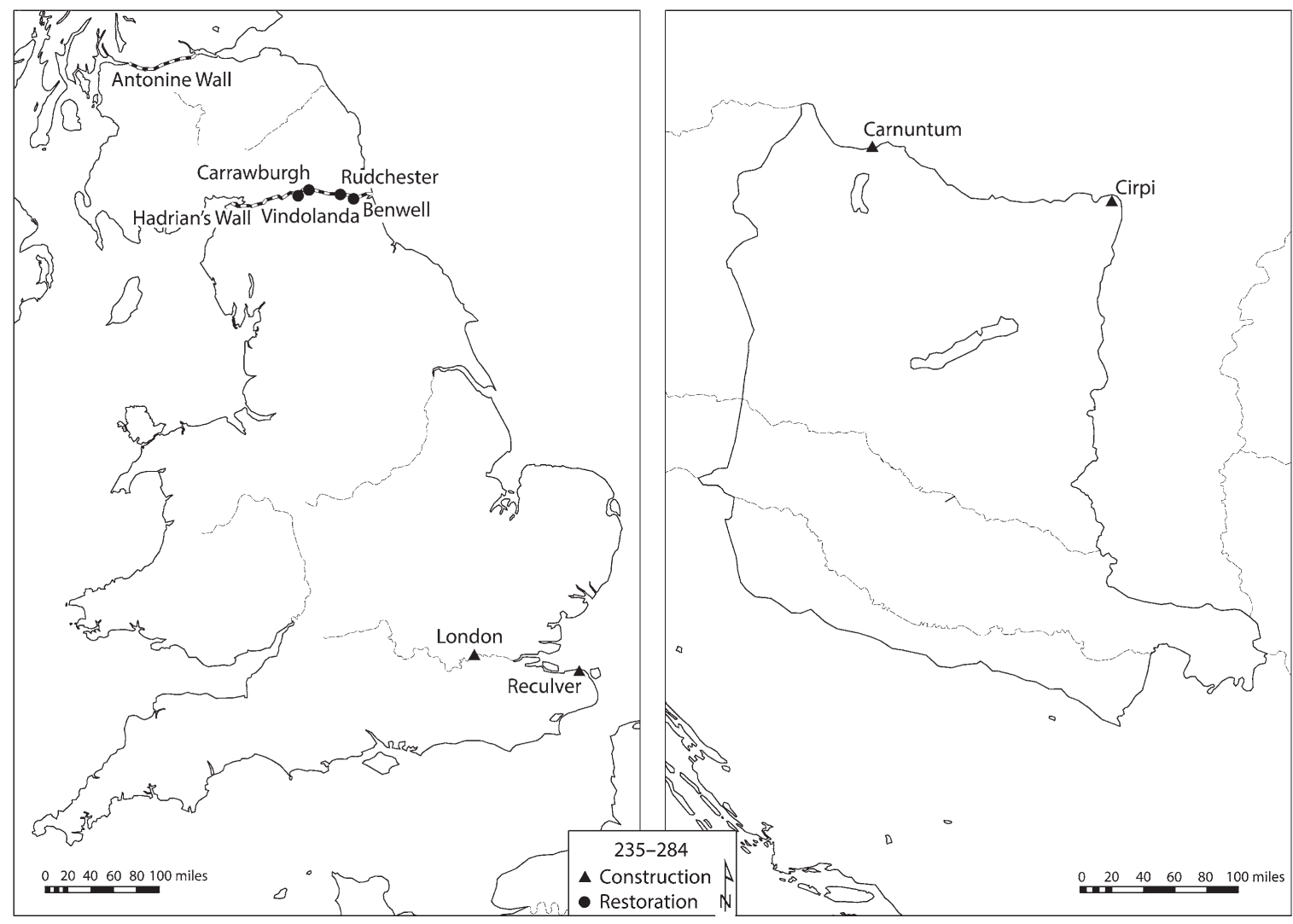

FIG. 9. Distribution of temple construction and repair or expansion between 235 and $284 \mathrm{CE}$ in Britain (left) and Pannonia (right). 


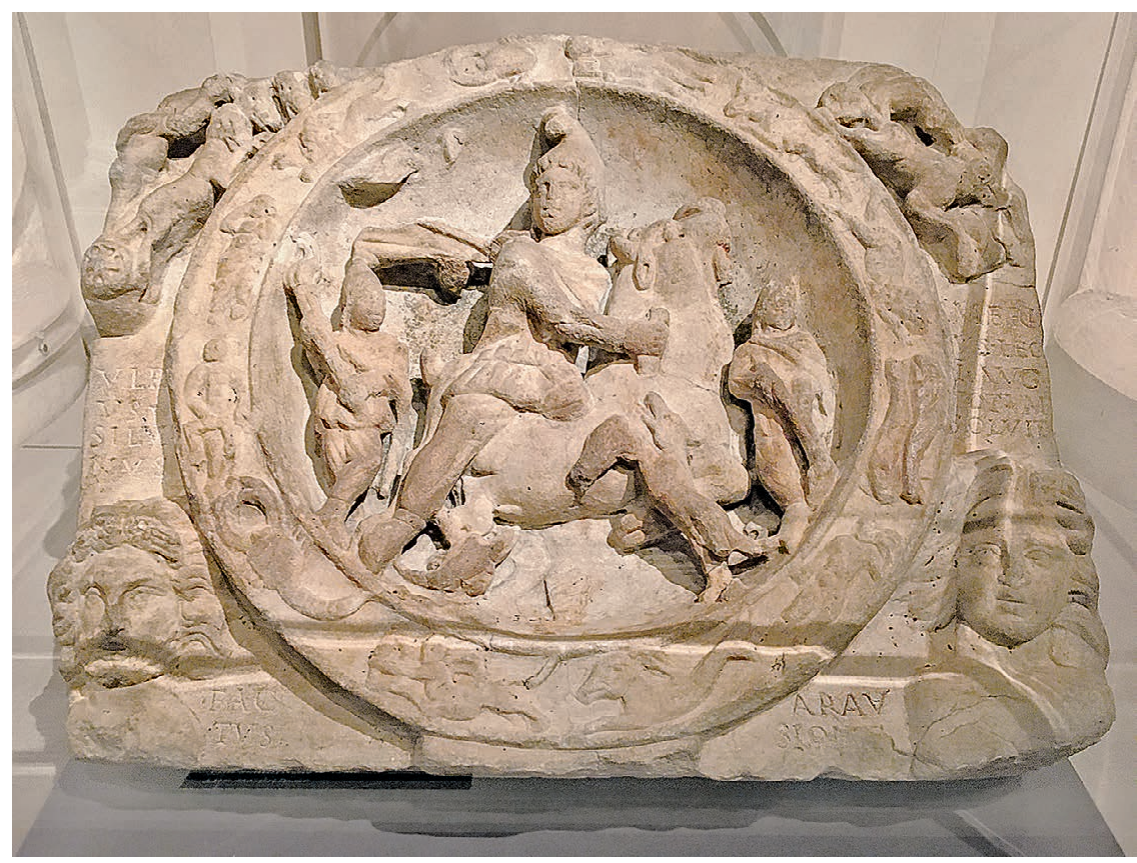

FIG. 10. Mithraic bull-slaying scene from the London Mithraeum, with inscription outside the tondo, dedicated by the veteran Ulpius Silvanus, white marble relief, mid third century CE, ht. 0.38 m. London, Museum of London, inv. no. A 16933.

(most famously) the Jupiter altars at Maryport. ${ }^{27}$ At Carrawburgh, the final restoration of the Mithraeum in the first decade of the fourth century used material from a neighboring nymphaeum (shrine to the nymphs) and also relocated the statue of a Mother Goddess-significantly weathered from a period of standing exposed to the elements-into the temple anteroom..$^{28}$ Similarly, the Housesteads Mithraeum, which was abandoned by the early fourth century, was found to contain altars to Cocidius and Jupiter as well as to Mars and Victory, which were obtained perhaps from other temples..$^{29}$ Elsewhere in Britain, there were numerous military installations erected from the mid third to the early fourth century, including the shore forts along the southern and eastern coasts and other smaller coastal fortifications such as Cardiff and Lancaster, but none of these sites has yielded evidence for the presence of temples. ${ }^{30}$ At Richborough, the latest

\footnotetext{
${ }^{27}$ Bewcastle: Collingwood and Wright 1965, no. 990. Carrawburgh: Collingwood and Wright 1965, no. 1538. Ribchester: Collingwood and Wright 1965, no. 587. South Shields: Tomlin et al. 2009, nos. 3268, 3269. Maryport: Haynes and Wilmott 2012.

${ }^{28}$ Richmond et al. 1951, 30.

${ }^{29}$ Walsh 2018a, 101-3.

${ }^{30}$ Pearson 2002, 2003.
}

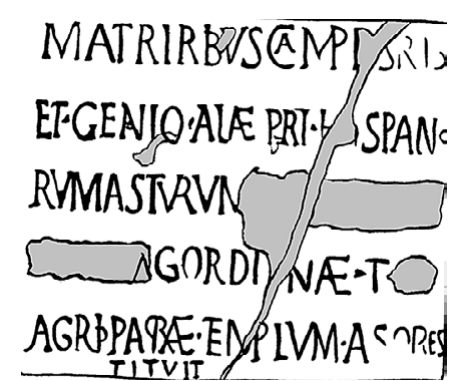

FIG. 11. Dedication to the Mother Goddesses of the Paradeground and the Genius of the First Cavalry Regiment of Asturian Spaniards from Benwell, sandstone dedicatory slab, $238 \mathrm{CE}$, ht. 0.4 m. Newcastle, Great North Museum, inv. no. 1864.5.14 (modified from Vanderbilt 2017, no. 1334).

excavations have indicated that two nearby temples, originally thought to be Tetrarchic in date, are more likely to have been constructed in the first or second century and to have been out of use by the latter half of the third century. ${ }^{31}$

\footnotetext{
${ }^{31}$ The temples were originally dated by Bushe-Fox based on his 1920s excavations (1932, 34-36). However, a recent and unpublished excavation by Wilmott has shown that the temples are late first to early second century in date and that the Tetrarchic-period deposits cut into the abandoned temples (Wilmott pers. comm. 24 August 2018).
} 


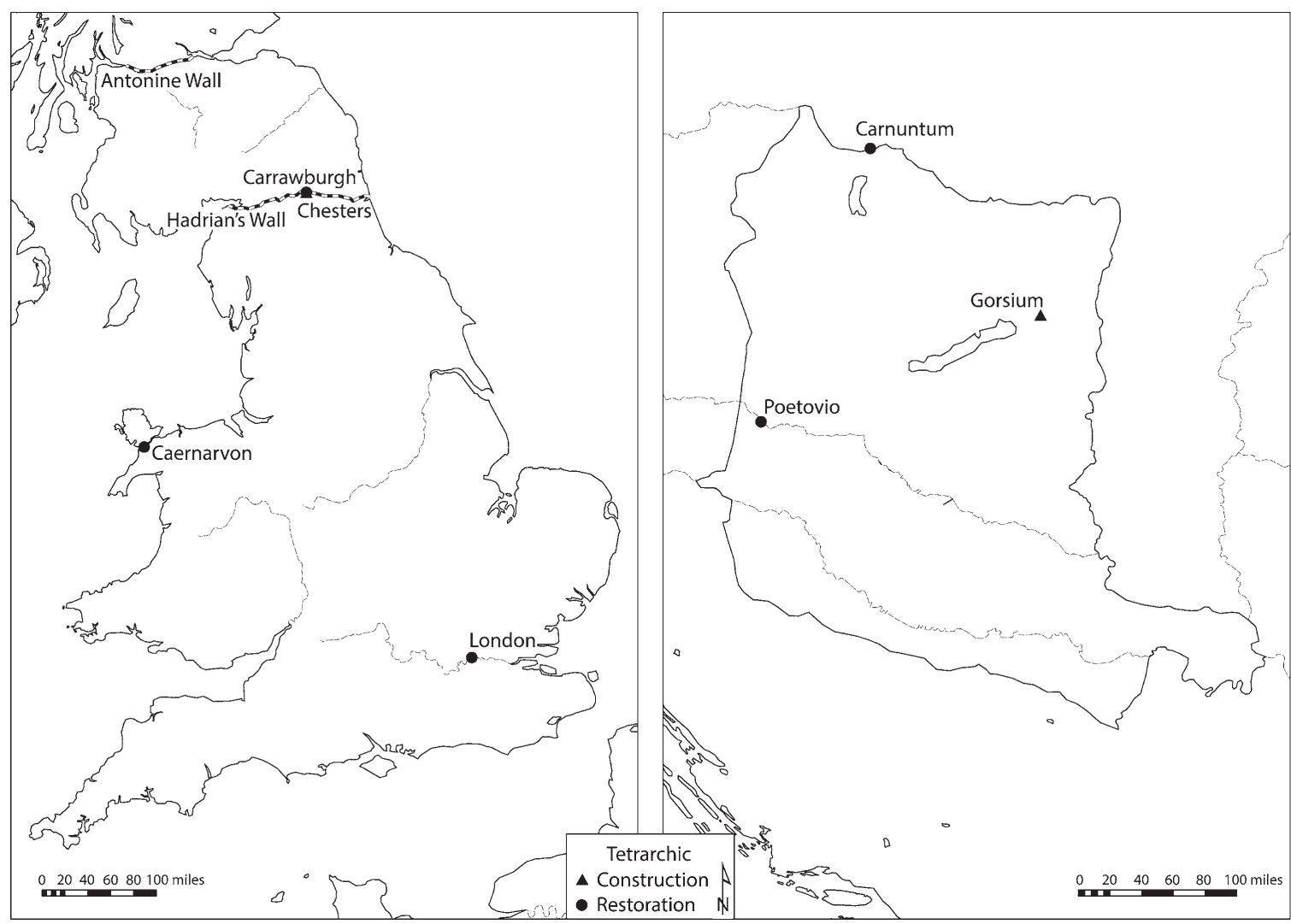

FIG. 12. Distribution of temple construction and repair or expansion in the Tetrarchic period (284-324 CE) in Britain (left) and Pannonia (right).

\section{TEMPLES IN PANNONIA}

The patterns of construction and repair evident in Britain find strong parallels with the evidence from the Danubian province of Pannonia (fig. 13). As I have already surveyed the Pannonian evidence as part of a wider study on temple building and repair in the Upper Danube provinces in a previous article, ${ }^{32}$ it suffices here to give a brief overview. In Pannonia, a similar rise in temple construction and repair in relation to the military community also occurred from the Nervan-Hadrianic period to the reign of the Severans (see figs. 2, 4, 6, 9, and 12), most notable at sites including Aquincum, Brigetio, Carnuntum, Gorisum, and Intercisa. ${ }^{33}$ The corpus of extant inscriptions from

\footnotetext{
${ }^{32}$ Walsh 2016 a.

${ }^{33}$ For the list of temples built and repaired at these locations, with complete references, see Walsh 2016a, 222-27. In that article, I incorrectly stated that Temple A in the Heliopolitan complex at Carnuntum was built in the Severan period; the temple precinct did undergo building work at that time, but the temple itself is from the first half of the second century.
}

Pannonia indicates that, as in Britain, soldiers ranging from rank-and-file to legates spent significant sums on temples, particularly under the Severans. Military personnel who funded the construction or repair of a temple often dedicated this work to the health of the emperor and his family, as at such locations as Ad Statuas, Brigetio, Carnuntum, Cirpi, and Intercisa. ${ }^{34}$ However, unlike in Britain, inscriptions found in Pannonia attest to the Severans themselves taking an active role in temple construction and repair at Gorsium, Intercisa, and Pone Navata. ${ }^{35}$ Additionally, as in Britain,

${ }^{34}$ Ad Statuas: AÉpigr 1947, no. 36 = Die römischen Inschriften Ungarns (hereafter RIU) 6,645=AÉpigr 2000, no. 1202. Brigetio: CIL 3 10984 = ILS 5417a = RIU2, 413 = AÉpigr 1891, no. 79 . Carnuntum: AÉpigr 2000, no. 1209 = AÉpigr 1992, no. 1412. Cirpi: AÉpigr 1983, no. 776b. Intercisa: AÉpigr 1973, no. 437bis = RIU 6, 1490; AÉpigr 1910, no. 141 = ILS 9155 = RIU 5, 1104; AÉpigr 1968, no. 429 = AÉpigr 1910, no. $140=$ RIU 5, 1059.

${ }^{35} \mathrm{~A}$ review of this evidence can be found in Walsh 2016a. Severus also funded the repair of temples to Terra Matris at Rudnik (CIL $36313=$ CIL 3 8333) and to Asklepius at Iuvavum (CIL 3 11762) in the neighboring provinces of Upper Moesia 


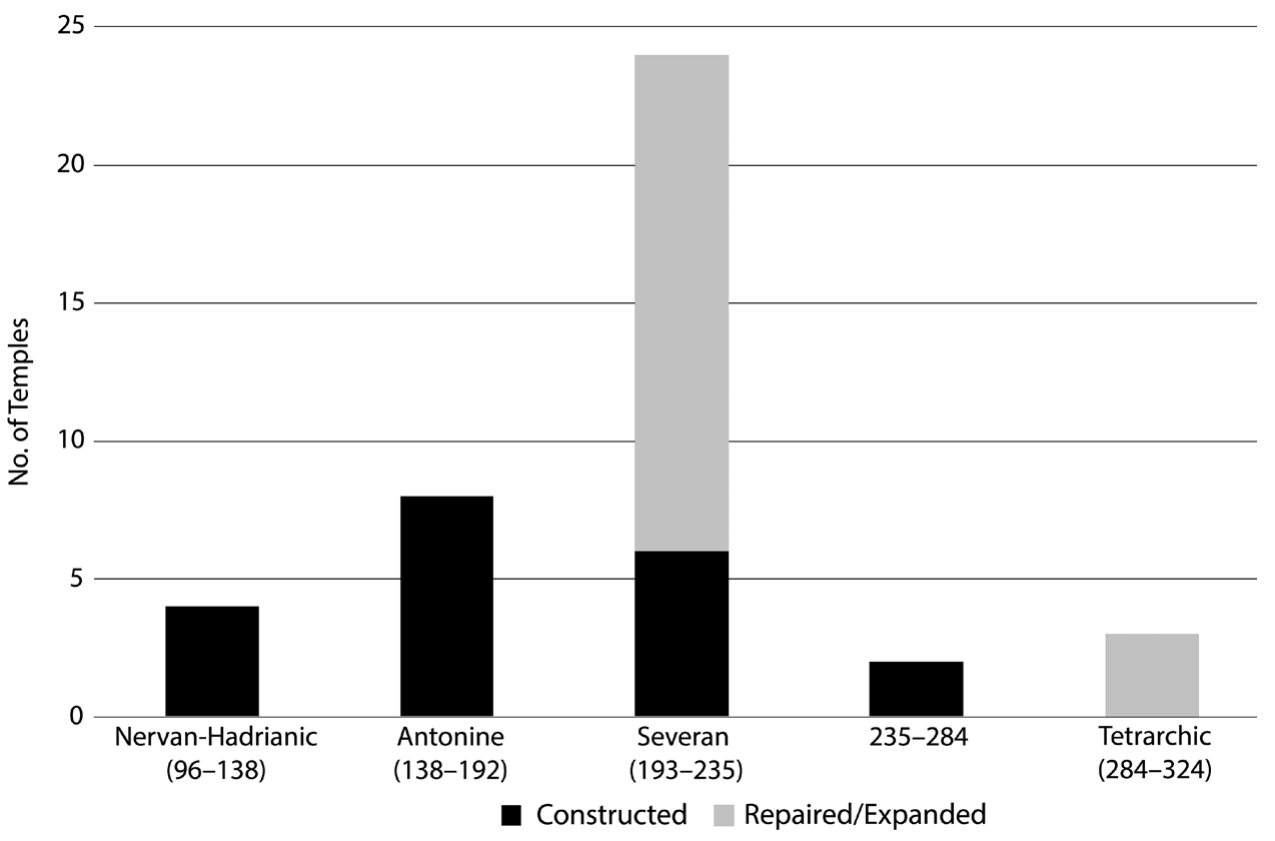

FIG. 13. Construction and repair or expansion of temples associated with the military in Pannonia.

temples to Mithras and Jupiter Dolichenus became increasingly common in the mid second to early third centuries. There were more temples of a substantial size connected to the military in Pannonia than in Britain; these include eight extant examples each covering more than $100 \mathrm{~m}^{2}$, seven of which are found at two sites, Gorsium and Carnuntum, and most of which are related to the state cults (table 2). ${ }^{36}$ The size of the Mithraeum at Carnuntum (about $298 \mathrm{~m}^{2}$ ) is unusual in Pannonia, as it covers more than double the area of the next largest Pannonian Mithraeum: that in the civilian town of Aquincum (about $150 \mathrm{~m}^{2}$, also known as Aquincum II or the Mithraeum of Symphorus) $;^{37}$ it is in fact one of the largest Mithraea ever discovered. However, the inner cella of the Carnuntum Mithraeum only covers approximately $95 \mathrm{~m}^{2}$; most of the temple consists of anterooms, and it is probable that the size of the congregation was limited, as was the norm for Mithraea.

The parallels between Pannonia and Britain continue into the mid third century, as in Pannonia there is also a considerable decline in building activity relat-

\footnotetext{
and Noricum, respectively.

${ }^{36}$ Temple 3 at Pfaffenberg has also been identified as a Dolichenum; see Schwarzer 2012, 156-57.

${ }^{37}$ Vermaseren 1959-1960, 2: no. 1767.
}

ing to temples and shrines connected to the military. Indeed, the decline in Pannonia is even more abrupt, with just five temples exhibiting investment after the Severan period. These include the construction of a temple to Silvanus at Cirpi, to the Heliopolitan Triad at Carnuntum (both in the mid third century), and possibly to Jupiter Dolichenus at Gorsium. ${ }^{38}$ The other two instances consist of repairs undertaken on two Mithraea: one at Carnuntum by the second Tetrarchy in $308 \mathrm{CE}$ (fig. 14) ${ }^{39}$ and another by a dux (general) at Poetovio around the same time. ${ }^{40}$ Unfortunately, the dedication recording the repairs to a Mithraeum at Carnuntum-which was inscribed on an altar and referred to Mithras as the protector of the Tetrarchs' imperium - was first recorded with no archaeological context, but the large Mithraeum at Carnuntum mentioned above is likely to have been the recipient of the Tetrarchs' patronage, as opposed to the smaller

\footnotetext{
${ }^{38}$ Supra n. 33. On the possible Dolichenum at Gorsium, see Fedak 1991.

${ }^{39}$ CIL 34413 = ILS 659 = Vermaseren 1959-1960, 2: no. 1698. “D(eo) S(oli) I(nvicto) M(ithrae) | fautori imperii sui | Iovii et Herculii | religiosissimi | Augusti et Caesares | sacrarium | restituerunt" (To the unconquered sun-god Mithras, protector of their imperium; the Jovi and Heruculi, the most religious Augustuses and Caesars, have restored the shrine). My translation.

${ }^{40}$ Walsh 2016a, 227.
} 
TABLE 2. Sizes of extant temples associated with the military in Pannonia.

\begin{tabular}{lcl}
\hline Location and Structure & Size $\left(\sim \mathrm{m}^{2}\right)$ & \multicolumn{1}{c}{ Reference } \\
\hline Gorsium, imperial cult temple & 512 & Fitz 2004, 200 \\
Carnuntum, Mithraeum III & 298 & Vermaseren 1956-1960, 2: no. 1682 \\
Carnuntum, Pfaffenberg II & 244 & Stiglitz et al. 1977, 710 \\
Gorsium, temple (Building 42) & 220 & Fitz 2004, 200 \\
Gorsium, Marcus Aurelius temple & 220 & Fitz 2004, 200 \\
Carnuntum, Epona temple & 210 & Jobst and Weber 1989, 352 \\
Carnuntum, Dolichenum & 130 & Schwarzer 2012, 190 \\
Vetus Salina, Dolichenum & 102 & Schwarzer 2012, 190 \\
Poetovio, Mithraeum II & 77 & Vermaseren 1956-1960, 2: no. 1509 \\
Carnuntum, Liber and Libera temple & 63 & Kandler 2004, 57 \\
Carnuntum, Heliopolitan Triad, Temple B & 49 & Eschbaumer et al. 2003, 133 \\
Aquincum, Mithraeum V & 48 & Póczy 1986, 217 \\
Carnuntum, Heliopolitan Triad, Temple A & 46 & Eschbaumer et al. 2003, 133 \\
Carnuntum, Pfaffenberg, Temple I & 45 & Stiglitz et al. 1977, 710 \\
Carnuntum, Silvanus and Quadruviae temple & 39 & Jobst 1983, 163 \\
Brigetio, Dolichenum & 32 & Schwarzer 2012, 190 \\
Carnuntum, Pfaffenberg, Temple III & 32 & Stiglitz et al. 1977, 710 \\
Brigetio, Mithraeum & 31 & Vermaseren 1956-1960, 2: no. 1723 \\
Fertörákos, Mithraeum & 23 & Vermaseren 1956-1960, 2: no. 1636 \\
\hline
\end{tabular}

Mithraeum near the Pfaffenberg temple complex just outside the town ${ }^{41}$ From the extant evidence, the restoration of the large Mithraeum was not very extravagant, consisting of the construction of an anteroom and the installation of a large altar decorated with depictions of the winds and seasons. Even the altar inscribed with the dedication was reused and in itself represented only a limited investment. ${ }^{42}$ However, the paucity of evidence for the Tetrarchs funding the construction or repair of temples outside their private estates, such as Split and Romuliana, ${ }^{43}$ and the fact that no previous emperors had made such a declaration of support for the Mithras cult, indicates that this dedication was made with considerable forethought.

Finally, just as military temples were used as sources of spolia in fourth-century Britain, so too were those

\footnotetext{
${ }^{41}$ On the smaller Mithraeum at Carnuntum, see Vermaseren 1959-1960, 2: nos. 1664-80.

${ }^{42}$ Walsh 2018a, 109-10.

${ }^{43}$ Lavan 2011, xliii-xliv. Split: Wilkes 1993, 52-56. Romuliana: Srejović 1993, 140-44.
}

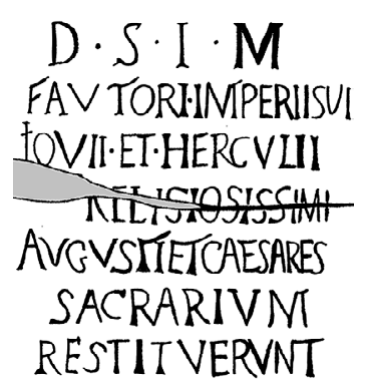

FIG. 14. Inscription on the reused altar dedicated to Mithras by the Tetrarchs at Carnuntum, marble altar, 308 CE, ht. ca. $0.7 \mathrm{~m}$. Bad Deutsch-Altenburg, Museum Carnuntinum (adapted from Osnabrügge 2017, fig. 1).

of Pannonia in the Tetrarchic period. Most notable is the site of Gorsium, which had been the imperial cult center for the region, with a large precinct containing temples dedicated to various emperors and gods, for which soldiers served as priests. The town was largely destroyed in the late third century and subsequently rebuilt in the Tetrarchic period. Yet, rather than rebuild any of these temples, the inhabitants instead mined the 
ruins for spolia, and the site was then used for public buildings with roof tiles stamped with the mark of the legio II Adiutrix. ${ }^{44}$ Thus, despite the considerable number of soldiers still stationed in both Britain and Pannonia at the turn of the fourth century, there is little evidence that they viewed temples as worthwhile investments.

\section{CAUSES OF TEMPLE DECLINE}

\section{Lack of Imperial Stimulus After $211 \mathrm{CE}$}

Many emperors from Augustus to Septimius Severus were avid temple builders. According to the Res Gestae, Augustus built 16 temples and restored a further 82; the Flavians were responsible for the construction and renovation of numerous temples; Hadrian was involved in the building work of about 20 temples and shrines; and the Historia Augusta notes that Septimius Severus' restoration of temples in Rome was particularly praiseworthy. ${ }^{45}$ The Historia Augusta, which was written sometime in the fourth century, is a document fraught with inaccuracies, but there is no reason to doubt that Severus was an active temple patron and that he encouraged others to follow his example, at least in areas that held a particular connection to him. Severus' homeland of North Africa as well as Rome itself have both produced ample archaeological evidence for extensive construction work in the Severan period. ${ }^{46}$ It is therefore unsurprising that the height of temple building in both Britain and Pannonia coincided with extended periods in which the imperial court, under Severus, was present in these provinces. It had been while serving as governor of Pannonia in 193 CE that Septimius Severus had made his bid for the throne, and he retained a close affiliation with the region throughout his reign. ${ }^{47}$ Clearly, Severus wished to encourage the development of the urban landscape of the Danube frontier; as noted, the imperial family paid for several temples in this region and for various other public buildings at Aquincum, Brigetio, Cibalae,

\footnotetext{
${ }^{44}$ Poulter 1992, 110-11; Fitz and Fedak 1993, 270-72; Christie 2011, 125.

${ }^{45} R G$ 19-21; on the Flavians, see Stamper 2005, 151-72; on Hadrian, see Boatwright 2000, 127-40; on Septimius Severus, see SHA, Sev. 23.1.

${ }^{46} \mathrm{On}$ the Severan building programs in Rome and North Africa, see Wilson 2007.

${ }^{47}$ Severus returned to Pannonia on at least two occasions during his reign (Birley 1988, 124, 126).
}

Carnuntum, and possibly Savaria. ${ }^{48} \mathrm{He}$ also elevated the civilian towns of Carnuntum and Aquincum to the rank of colonia. ${ }^{49}$ Severus' keenness that the towns of the region should continue to develop is made clear in a rescript from Flavia Solva, in the neighboring province of Noricum, that records the emperor's demand that people not attempt to escape their civic duties. ${ }^{50}$ The example set by the emperor clearly paid dividends, as the Danube saw a notable increase in urban development during the Severan period, particularly in the more militarized frontier regions. ${ }^{51}$ Among those who embraced the Severan program of development were soldiers, who financed the construction and repair of temples and often dedicated these projects to the welfare of Severan emperors.

The last few years of Severus' life were spent, in the company of his sons, on a campaign in northern Britain, which saw extensive building work undertaken on fortifications, as in Pannonia. Evidence comes from forts around the Pennines, as well as at Caernarvon, Chesters, Corbridge, South Shields, Vindolanda, and along Hadrian's Wall itself. ${ }^{52}$ In fact, the extensive construction undertaken in Severus' reign led subsequent Roman authors to believe that it was Severus, rather than Hadrian, who ordered the wall to be built. ${ }^{53}$ There is no evidence indicating that Severus or other members of his dynasty constructed temples in Britain, but it is reasonable to assume that he would have advocated similar investment here as on the Danube, with the notable rise in investment in Mithraea, Dolichena, and temples to Isis and Sarapis in Britain echoing the popularity these cults were enjoying along the Upper Danube region at this time. Certainly, the cults of Jupiter Dolichenus and Isis and Sarapis held some connection with the Severans, ${ }^{54}$ while the cult of Mithras was a particularly effective tool in maintaining the secular hierarchy through its grade structure and

\footnotetext{
${ }^{48}$ Mráv 2013, 208-17.

${ }^{49}$ Mócsy 1974, 218.

${ }^{50}$ Johnson et al. 1961, 225 n. 276.

${ }^{51}$ Mócsy 1974, 217-40.

${ }^{52}$ Southern 2016, 199-210.

${ }^{53}$ Aurelius Victor 20.18; Eutr. 8.19.1; SHA, Sev. 18.2.

${ }^{54}$ On the relationship between the Severans and these deities, see Birley 1988, 35, 138, 194. For reasons not clear, all the priests of Jupiter Dolichenus in Pannonia came together at Gorsium and recorded their meeting on a votive altar; this may relate to the visit of Severus and Caracalla in 202 CE (Mócsy 1974, 256; Wilson 2007, 323).
} 
the honor it paid to the imperial family (see below). In any case, there is a clear positive correlahtion between the presence of the Severans and the inclination of soldiers to engage in the construction and repair of temples.

In contrast, following Severus' death, subsequent members of the Severan dynasty never returned to Britain or Pannonia, and the rapid turnover of emperors and usurpers that followed them meant few had the time to engage in a sustained program of benefaction in the way that Severus and his predecessors had..$^{55} \mathrm{~A}$ lack of direct stimulus from the imperial government would have been felt particularly in Britain, where it would be decades before an emperor was present again. Even in 260-274 CE, when Britain was part of the breakaway Gallic empire, there is little evidence for any of the Gallic emperors spending time in Britain. ${ }^{56}$ For these emperors, of much greater concern were the Rhine frontier and the official Roman authorities to the west. Aurelian's reconquest of the Gallic empire in $274 \mathrm{CE}$ did not bring him to visit Britain, with the campaign taking him only as far as Châlons. However, even during the successive reigns of Carausius, Allectus, and Constantius I (286-306 CE), all of whom spent time in Britain, there is no extant evidence for these emperors funding the construction or repair of temples, which is particularly striking in the case of the first two, as their domain was largely limited to this province. Although far from the only reason to invest in temples, such a decline in stimulus from the imperial court would have lessened the impetus for soldiers to fund temples, especially as, according to inscriptions from previous generations, this had been done at least in part for the welfare of the emperors. In areas such as Pannonia, it is also possible that a sense of disillusionment with funding temples grew after the end of the Severan dynasty, when Maximinus Thrax became emperor (r. 235-238 CE). According to Herodian, Maximinus stripped temples of their wealth, and there is archaeological evidence from the Rhine and Danube regions of Dolichena being destroyed at this time. ${ }^{57}$ What would be the incentive for soldiers to continue funding temples, if emperors were more inclined to steal from temples than maintain them?

\footnotetext{
${ }^{55}$ Only the reign of Gallienus, when his time as co-emperor with Valerian is included, lasted longer than a decade.

${ }^{56}$ Drinkwater 1987, 168.

${ }^{57}$ Hdn. 7.3.5; Tóth 1973.
}

Logistical Problems

The ability for soldiers to fund the construction and repair of temples would certainly have become more challenging in the third century, as the value of their wages had decreased significantly in comparison to earlier periods. In $300 \mathrm{CE}$, the annual stipendum given to soldiers was the same as in the previous century, yet, because of inflation, this pay had become only nominal. Even with the additional funds that soldiers received from donatives on emperors' accessions and birthdays, they were still far less affluent than their Severan predecessors. ${ }^{58}$ The decline of vici along Hadrian's Wall in the latter half of the third century, such as at Housesteads, Wallsend, Vindolanda, and Piercebridge ${ }^{59}$ might have been symptomatic of the reduced wealth of the soldiery, for those who sought to make money from them (e.g., merchants, craftsmen, and prostitutes) were better served seeking sources of revenue elsewhere. ${ }^{60}$ Relative to the soldiers' income, temple construction and repair had become increasingly expensive, which doubtless affected the capability (or desire) of soldiers to pay for them.

The apparent reduction, in the third to fourth centuries, in the size of garrisons in Britain also made it more difficult for soldiers to fund building projects. At locations such as Great Chesters, Housesteads, and Wallsend, changes to the style of barrack blocks in the third century are telling, with each unit that had originally been designed for ten men now seemingly holding only five or six. ${ }^{61}$ As Hassall has observed, the forts constructed in the third century and later tended to be much smaller compared to those erected in earlier periods, suggesting smaller-sized garrisons. ${ }^{62}$ The decline of the vici can also be linked to the smaller garrisons, for not only were soldiers no longer attractive customers in regard to their wealth, but also their numbers were smaller. Even if they banded together to offset the reduced value of their wages, their limited numbers would have made it difficult for soldiers to pay for the

\footnotetext{
${ }^{58}$ Jones 1964, 623, 1257 n. 31; Southern and Dixon 1996, 77; Brickstock 2010.

${ }^{59}$ Housesteads: Rushworth 2009, 264-68. Wallsend: Hodgson 2009, 69. Vindolanda: Birley 2009, 162-68. Piercebridge: Cool 2008.

${ }^{60}$ Southern 2016, 308-10.

${ }^{61}$ For an overview of changes to the barrack blocks at these sites, see Daniels 1980; Rushworth 2009, 299-314; Wilmott 2010, 10-12.

${ }^{62}$ Hassall 2017, 228.
} 
construction or repair of a temple. Furthermore, the support for certain temples would decline simply because their congregations moved elsewhere; smaller communities meant less variability among individual religious choices.

\section{Changing Approaches to Euergetism}

There were, however, some residents in these forts who could afford to construct or repair temples: the commanders. These were men of higher status, often in this era coming from equestrian backgrounds, ${ }^{63}$ and they occupied lavish new residences (praetoria) built for them at Piercebridge, Vindolanda, Binchester, South Shields, and possibly at Birdoswald, in the late third to early fourth centuries. ${ }^{64}$ Wilmott observes that "these buildings suggest that many garrisons were local centers of power, presided over by highly influential officers." ${ }^{65}$ Seemingly, at least these men could afford to support the construction and repair of temples, as their predecessors in these roles had done. ${ }^{66}$ Their well-todo civilian counterparts across Britain continued to do so in rural areas, for there is a clear correlation between investment in rural temples (i.e., those in seemingly isolated areas, on estates, and near small villages) and the presence of villas, with both reaching their apogee in the early fourth century. ${ }^{67}$ Yet, in both Britain and Pannonia, there is a lack of evidence for high-ranking officers supporting or repairing temples after the mid third century, with the exception of the Mithraeum repaired by a dux at Poetovio mentioned above. ${ }^{68}$

The lack of engagement in temples on the part of army officers might be explained by the diminished popularity of euergetism in Roman society during the third century. Across many provinces, civic building was already in decline by the early third century, largely because the role of town councillor (decurion

\footnotetext{
${ }^{63}$ Osier 1977, 674-83.

${ }^{64}$ Piercebridge: Cool and Mason 2008, 59-80. Vindolanda: Collins 2012, 92-93. Binchester: Ferris 2011, 76-114. South Shields: Collins 2012, 88. Birdoswald: Wilmott 2001, 118.

${ }^{65}$ Wilmott 2010, 11.

${ }^{66}$ Given that a top-ranking centurion would have earned up to 30 times the basic rate of pay (Speidel 1992, 105), one would presume that those ranked above them, even with inflation, would have been well compensated.

${ }^{67}$ Smith 2001, 144. This was not the case in Pannonia, however, where villa owners prioritized the construction of large defensive walls, which British villas never adopted; see Mulvin 2002.

${ }^{68}$ Supra n. 40.
}

or duovir), which included funding such activities, had become far less appealing precisely because of the significant financial outlays required of its holder. The aforementioned rescript from Flavia Solva is an indication of how enthusiasm for such investments was waning by this time. ${ }^{69}$ From the early third century, social advancement was more readily sought at the imperial court, in the military, or by focusing on one's rural estates. ${ }^{70}$ Instances in the historical and archaeological records of large building projects from earlier periods that were never completed hint that some may have begun to question the necessity of filling towns with unused, half-finished structures. ${ }^{71}$ A decreased enthusiasm for euergetism is clear in both third-century Britain and Pannonia. In Pannonia, public building quickly dwindled after the end of the Severan period, while in Britain, despite some resurgence in the late third century, urban development never again reached the heights of the Claudian to Antonine periods. ${ }^{72}$ It is difficult to believe that commanders of forts would wish to shoulder a burden that military service had effectively allowed them to avoid by removing them from the obligations of the civic sphere. Additionally, as noted above, the apparent decline in the number of soldiers, along with other members of the military community housed in the vici, meant that there were fewer people to admire a display of generosity.

\section{The Focus on Ritual}

Another possible reason for declining investment in temples among the military community is that such structures were not deemed a necessity for the required religious observances of the army. In the Roman world, rituals, and their correct performance, were central to proper religious conduct, and nowhere more so than in the army. As documents such as the Feriale Duranum (234-235 CE) make clear, ${ }^{73}$ membership in the Roman army meant partaking in numerous official religious rituals and festivals that instilled a level

\footnotetext{
${ }^{69}$ Supra n. 49.

${ }^{70}$ Ward-Perkins 1984, 15-17.

${ }^{71}$ Examples of unfinished buildings in the archaeological record include the forum in London (Faulkner 2000, 33) and the basilica at Silchester (Fulford 1985, 59). The frustration that Pliny (Ep. 10.37, 39), while governor of Bithynia, expressed to Trajan regarding such matters is an indication of a disillusionment with such practices even in the early second century.

${ }^{72}$ Walsh 2018a, 51, 53-54.

${ }^{73}$ ANRW 2.16.1:1481-88; Hoey et al. 1940.
} 
of uniformity across what was a considerably varied group and formed a cornerstone of the military community.

One of the principal rituals of the military, as well as in Roman society generally, was sacrifice. In a military context, sacrifices could be conducted on a variety of occasions, such as before a battle or campaign (lustratio), before the dismissal of veterans, or following the fulfillment of special assignments. ${ }^{74}$ For the lustratio, oxen, pigs, and sheep were sacrificed, and the meat was doled out to the soldiers. Sacrifices could also include offerings of wine and incense. An image of a sacrifice in a military context, dating to ca. $239 \mathrm{CE}$, was found at Dura-Europos and shows the tribunus Terentius undertaking a sacrifice in front of a military standard and his men. Based on papyrus fragments from DuraEuropos, Pekàry has observed that this fresco depicts a ceremony, conducted every morning in imperial camps, in which the soldiers received the watchword of the day and reiterated their loyalty to the emperor. ${ }^{75}$ The contrast between the continuing importance of sacrifice and the declining importance of temples in the late third century is evident on coinage. Temples appear regularly on the coinage of earlier emperors - who, as observed above, were also keen temple builders - and signal not only the emperors' generosity to their subjects but also their devotion to the gods. ${ }^{76}$ However, during the reign of Aurelian (270-275 CE), just one example is known of a coin bearing a depiction of a temple, and, under the Diarchy (285-293 CE) and the first Tetrarchy (293-306 $\mathrm{CE})$, temples never appear. ${ }^{77}$ Yet, images of sacrifice

\footnotetext{
${ }^{74}$ Hertz 2002.

${ }^{75}$ Pekàry 1986.

${ }^{76}$ ANRW 2.16.1:565. Examples of images of temples on imperial coinage: Vespasian: RIC 2:70, nos. 452-53, 463; 80, no. 553; 92, no. 656; 94, no. 681; 95, nos. 688-89; 97, nos. 703, 705; 101, no. 736; 102, no. 750; 105, no. 765; 108, no. 793. Trajan: RIC 2:285, nos. 575-76; 296, nos. 720-23; 308, no. 795; 310, no. 809 . Hadrian: RIC 2:347, no. 57; 396, no. 461; 397, no. 462; 399, no. 475; 403, nos. 519-523; 440, no. 784. Antoninus Pius: RIC 3:53, no. 227 ; 58 , no. 269 ; 60 , nos. $284-85$, 289 ; 62 , no. 296 ; 110 , no. 622 ; 113 , no. 651 ; 114 , no. 664 ; 115 , no. 673 ; 140 , no. 913 ; 141, no. 923 ; 142, no. 931 .

${ }^{77}$ Maximian did include images of temples on coins minted during his return from retirement (306-308 CE), when ruling in tandem with his son Maxentius in Italy. The reappearance of temples on his coinage can be linked with Maxentius' own building program in Rome, which included repairing the temple of Venus and Roma and the (possible) construction of the
}

remained common on coinage into the late third century, and the rituals depicted became more overtly military-focused. Coins often show the Tetrarchs as a group conducting a sacrifice in front of a military camp (fig. 15). ${ }^{78}$ On the Arch of Galerius in Thessaloniki, Galerius conducts a sacrifice in military uniform (fig. 16), ${ }^{79}$ a notable contrast to earlier monuments, such as Trajan's Column and the Arch of Marcus Aurelius, which depict the emperors conducting sacrifices in traditional civilian garb. ${ }^{80}$ Such symbolism makes it clear how important sacrifices continued to be to the success of the military, though temples do not figure in this iconography; rather, temples appear to have carried a separate message that was not intrinsically linked to sacrifices.

Oaths were also important rituals among those in the army. On joining the army, one took a religious oath to serve the emperor, and this was repeated twice yearly: once on 3 January and again on the date of the current emperor's accession. Oathtaking, as well as other military rituals, such as the dispensing of donatives, took place out in the open, usually on the parade grounds where the greatest number of soldiers could be gathered. ${ }^{81}$ Among the oaths sworn, one of the most important was to the standards. The power of these objects is often made clear in Roman literature and iconography. Examples of this include Caesar's account (BGall. 4.25) of his brave standardbearer, who led the landing in Britain, and the depiction on the Prima Porta statue of the triumphal return of Crassus' lost standards from the Parthians. ${ }^{82}$ The status of these objects had not changed in the later empire; they were still frequently depicted in iconography relating to the military (particularly on imperial arches and coinage), and Ammianus recalls how the sight of the standards galvanized Julian's cavalry in battle. ${ }^{83}$ Indeed, their continued religious significance

temple of the Divine Romulus in the forum; see Hekster 2000, 725-27.

${ }^{78}$ RIC 6: 175-78, nos. 100-36 (Treveri); 281-82, nos. 12-19 (Ticinum); 351-54, nos. 10-42 (Rome); 459-62, nos. 33-67 (Siscia); 529-30, nos. 1-11 (Hereclea); 555-56, nos. 18-23 (Nicomedia); 578-79, nos. 4-6 (Cyzicus); 616, nos. 31-33 (Antiochia); 661, nos. 7-8 (Alexandria).

${ }^{79}$ Rees 1993, 198.

${ }^{80}$ Boschung 2012, 310 .

${ }^{81}$ ANRW 2.16.1:1478-481.

${ }^{82}$ ANRW 2.16.1:1473-478.

${ }^{83}$ Ammianus, Res Gestae 20.4.18; Southern and Dixon 1996, $125-26$. 


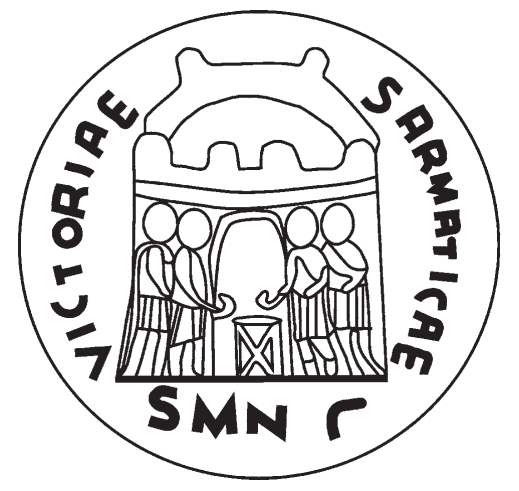

FIG. 15. The first Tetrarchy performing a sacrifice in front of a fort, depicted on the reverse of a silver coin (argenteus) of Diocletian from Nicomedia (RIC 6:555, no.19a); obverse: DIOCLETIANUS AUG; reverse: VICTORIAE SARMATICAE; ca. $295 \mathrm{CE}$, diam. ca. $1.7 \mathrm{~cm}$ (adapted from Woods 2017, fig. 1).

is highlighted by the appearance under Constantine of the military standard known as the labarum, on which the Chi-Rho symbol (the first two letters of "Christ" in Greek) initially appeared. ${ }^{84}$ Yet, the standards were not kept in a temple but rather, along with images of the emperor and imperial family, in a room in the camp headquarters from which they were brought out for festivals or in the event of a battle. Importantly, this room was deemed a shrine only because it held these sacred objects. ${ }^{85}$ Thus, the standards were of primary concern and the space itself only of secondary importance. When it was time to use these objects in rituals, they were brought out of the room and displayed in the open. As an inscription from Reculver makes clear, high-ranking individuals could refurbish the central shrine of the camp and have their name attached to it; this recognition in the heart of the camp may have garnered greater attention than any inscriptions on temples beyond the camp's walls. However, the shrine at Reculver was repaired in $238 \mathrm{CE}$, and there is no subsequent evidence for such central shrines being refurbished in later periods. ${ }^{86}$

The oaths, the location of the standards, and the performance of sacrifices all served to cement the fort commander's status through religious associations, without the aid of temples. First, the oaths bound soldiers to the emperor, but the commander was the

\footnotetext{
${ }^{84}$ Frakes 2012, 104.

${ }^{85}$ ANRW 2.16.1:1473-478.

${ }^{86}$ Tomlin et al. 2009, no. 3027 .
}

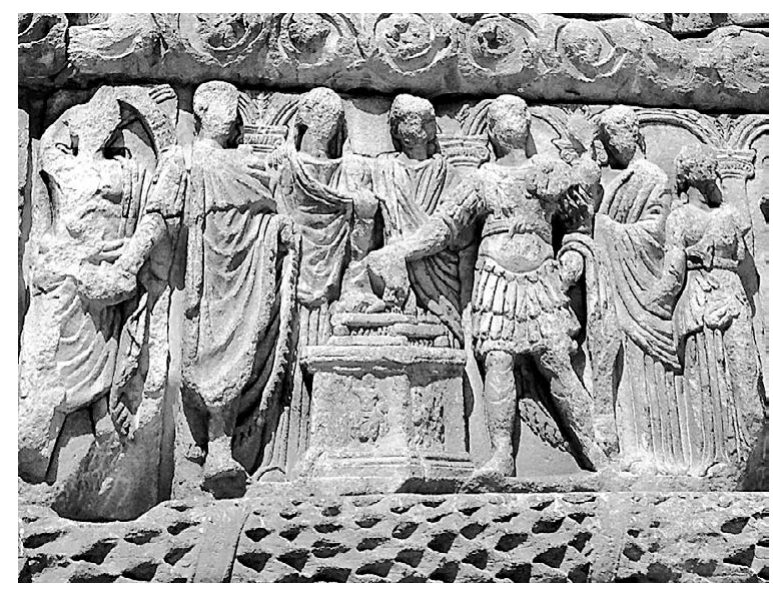

FIG. 16. Frieze on the south pier, east face of the Arch of Galerius, Thessaloniki. Galerius is depicted performing a sacrifice in military regalia.

emperor's representative; thus, swearing loyalty to the emperor meant obeying the commander's orders. Second, the commander's house was directly adjacent to the principia, and he was thus frequently in close proximity to the standards. Third, it fell to the commanders to conduct sacrifices to the gods, as shown in the Dura-Europos fresco. None of this, however, required a temple. A military commander, therefore, while he might live in a lavish accommodation, did not necessarily need to communicate his relationship with the divine in a fashion similar to his temple-building, villaowning civil counterpart. In short, the central rituals of the military never appear to have required temples for their performance.

The transformation of temple precincts into open spaces in fourth-century towns in Britain that had a notable military presence may also be a result of physical structures becoming less vital to the proper conduct of rituals. At Canterbury, although the temple precinct had been leveled by the mid fourth century and the area converted into a paved open space, it has been suggested that ritual activity continued at this location. Hassall has observed that Canterbury had direct access to four of the shore forts (Reculver, Richborough, Dover, and Lympe), and so soldiers stationed at these forts were probably billeted in the town ${ }^{87}$ None of these forts has produced temples, and it is curious that the main town of the region saw its temple precinct demolished rather than maintained. Canterbury was not

${ }^{87}$ Hassall 2017, 221. 
the only place this occurred; at Gloucester, the temple precinct was also leveled around the same time and a paved area laid in its place. Faulkner has argued that these spaces were created to facilitate gatherings of soldiers, and Rogers has suggested that, even without temples, these spaces were the sites of religious rituals, in addition to markets and other meetings. ${ }^{88}$ Could it be that the demolition of these temples and laying of paved areas were part of a larger shift, particularly in the military, away from temples as foci of religious activity to more open spaces that had multiple uses?

What is clear is that temples were no longer considered essential in the religious activities required for members of the military community. In earlier periods, when soldiers were paid more and were greater in number, when euergetism was popular in Roman society, and when emperors set a precedent for such activities, there was evidently considerable enthusiasm for building and repairing temples, but, from the later years of the Severan dynasty onward, clear transformations in these factors culminated in a rapid decline in the construction and repair of temples by soldiers and for soldiers. This did not mean the army was devoid of religious activity; indeed, far from it, for religious rituals and objects remained a central part of military life, and they served to promote the importance of structure and loyalty among their ranks.

\section{Changing Use of Space}

Finally, it is possible that, beginning in the early third century, spaces within forts were adapted to accommodate religious activities but these adapted spaces are not archaeologically visible. The Dolichenum inside the fort at Vindolanda and the Mithraeum inside the tribune's house at the Aquincum fort indicate that, although a rarity, it was possible for unofficial religious spaces (i.e., other than the shrine of the standards) to be installed in forts. Many of the vici along Hadrian's Wall appear to have almost completely disappeared by the turn of the fourth century, and certainly some of the former inhabitants of these extramural settlements moved inside the forts. If, as was postulated above, temples were increasingly viewed as superfluous among military communities, then there would be little reason to continue conducting rituals outside the forts. However, the conversion of spaces inside forts to a religious use is not easily detectable. The identifica-

\footnotetext{
${ }^{88}$ Faulkner 2000, 126-28; Rogers 2011, 125-29.
}

tion of the Dolichenum at Vindolanda and Mithraeum at Aquincum were only possible because the former contained two altars and the latter contained Mithraic wall paintings. In both cases, the identification of these as religious spaces relied heavily on good fortune, for, as we have seen in other examples, altars were often reused as spolia, and wall paintings rarely survive in regions such as Britain or Pannonia. Altars and inscriptions at other sites may have been fashioned from perishable materials that do not survive. Furthermore, as in the case of open spaces created in towns such as Canterbury and Gloucester, some spaces may have taken on a variety of functions of which the religious was only one, and the evidence for other forms of use may obscure detection of a religious function in the archaeological record. Thus, there are likely to have been more examples of structures inside forts that were converted to a religious use, particularly in later periods, but at present the archaeological evidence is not sufficient to explore this properly. It is also pertinent to note that, beginning in the late fourth century, structures that may have been churches began to appear within forts at locations such as Housesteads, Vindolanda, and Reculver in Britain, and in Germany at Boppard, Kaiseraugust, and Zurzach. ${ }^{89}$ If religious activity was now primarily conducted inside forts, then it is possible that the appearance of churches represents continuity in this regard.

\section{THE SURVIVAL OF DOLICHENA AND MITHRAEA}

As illustrated, not all religious structures connected to the military ceased to attract support, as Mithraea and Dolichena were exceptions to this decline. The continued prosperity of Mithraea is most apparent in Pannonia, where they constituted the most common form of building constructed or repaired in the third century. Some towns even contained up to four or five Mithraea active simultaneously, such as at Aquincum and Poetovio. Evidently, for the soldiers on the Danube, Mithras was among the most popular deities, if not the most popular. ${ }^{90}$

In these circumstances, the unprecedented decision of the Tetrarchs to repair a Mithraeum and declare Mithras the protector of their imperium during the meeting at Carnuntum in $308 \mathrm{CE}$ was quite logical.

\footnotetext{
${ }^{89}$ On Britain, see Petts 2016, 668-69; on the churches in German forts, see Brown 1971, 227-28.

${ }^{90}$ Walsh 2016b.
} 
As this conference was held in response to the rise of various usurpers, the Tetrarchs were in need of divine support that would resonate with the soldiery, and the popular Mithras was the obvious candidate. ${ }^{91}$ Furthermore, the cult provided an effective tool, desperately needed at the time, to reinforce the social structures of the Roman world with the emperor(s) at their head. It is clear from the epigraphic record that those who held the title of pater, the highest of the seven Mithraic grades, also held a higher secular position than the other members of their Mithraic community. For example, if a pater were a centurion, the other members of the Mithraic congregation would likely be rankand-file soldiers, and, if the pater were a freedman, the others were often slaves. That the highest echelons of the Mithraic hierarchy were open to only a select few is also illustrated by the fact that other than the title pater the Mithraic grade most frequently mentioned in the epigraphic record is the middle grade of leo, an indication that many initiates could not climb the Mithraic ladder any farther. The cult posed no threat to the established social order, as is demonstrated by the dedications made by Mithraic initiates in honor of emperors and their families. ${ }^{92}$ That such cults could be used positively was recognized by commanding officers who, despite never having been initiated into the Mysteries of Mithras, donated altars to Mithraea. ${ }^{93}$ It is unlikely that, given their own military backgrounds, the Tetrarchs would be unaware of how beneficial the cult could be in maintaining the loyalty of soldiers, particularly along the Danube, and they sought to use this to their advantage.

\footnotetext{
${ }^{91}$ It is worth noting that the Tetrarchs' support for the Mithras cult should not be confused with their support for the cult of the Unconquered Sun (Sol Invictus). The cult of Mithras is sometimes conflated with that of Sol because Sol appears in Mithraic iconography and inscriptions. However, the two cults remained distinct, even in the Tetrarchic period: for example, the Tetrarchs put Sol on their coinage but not Mithras; the Tetrarchs ordered a new temple to Sol at Como, but no indication they built new Mithraea; and there is no evidence that the cult of Sol continued to have any success in its own right along the Danube in the early fourth century. The Tetrarchs' support for Sol follows precedents set by earlier emperors, such as Augustus, Gallienus, and Aurelian, but their Mithraic dedication does not.

${ }^{92}$ Gordon 1972; Clauss 2000, 39-41. For Mithraic initiates honoring emperors, see Vermaseren 1956-1960, 1: nos. 53, $142,161,347,510,626,876$; 2: no. 2350.

${ }^{93}$ Clauss 2000, 34-37.
}

In Britain, the cult of Mithras was seemingly less successful than in Germany or Pannonia. Why this was remains a mystery, although undoubtedly some number of British Mithraea have either not survived in the archaeological record or have been recorded incorrectly. ${ }^{94}$ Yet, when one views the extant evidence for repairs carried out on Mithraea in Britain during the Tetrarchic period, in the context of a general dearth of evidence for the construction and repair of other temples, it is evident that the cult still enjoyed particularly strong support at places such as Carrawburgh and Caernarvon. ${ }^{95}$ The longevity of Mithraea in Britain compared to other types of temples is also reflected in the fact that some came to house images of deities that originated from other temples, such as the statuette of the Mother Goddess at Carrawburgh and the representations of various deities found in the London Mithraeum. ${ }^{96}$ It is possible that the worship of these deities had to be relocated to Mithraea (or at least their anterooms) when their own temples had fallen into disrepair.

Why, then, did Mithraea retain such support into the early fourth century? Answers lie in the relationship between their design and, for one thing, the limits this placed on congregation numbers, and, for another, the nature of the rituals held in the Mithraeum. Mithraea were generally small in size (typically less than $100 \mathrm{~m}^{2}$ ) and had a set plan that was replicated across the Roman empire. The standard layout of a Mithraeum consisted of at least one antechamber that led to an inner sanctuary with two parallel benches, one on each side of a nave that terminated in front of the cult image (fig. 17). Mithraea did not have windows or any external decoration. In practical terms, such a design made them relatively easy to build and maintain and would have

\footnotetext{
${ }^{94}$ The presence of Mithraea is suggested by finds at various sites. For example, a bull-slaying scene has been found at York (Vermaseren 1956-1960, 1: no. 835), and Mithraic inscriptions have been found at Caerleon (Vermaseren 1956-1960, 1: no. 809) and Carlisle (Vermaseren 1956-1960, 1: no. 875).

${ }^{95}$ I have argued that the so-called church at Butt Road, Colchester, was in fact a Mithraeum erected in the Tetrarchic period (Walsh 2018b). If I am correct, the suggestion by Hassall (2017, 221) that Colchester might have been used to billet soldiers at this time raises the possibility that some of these men were the Mithraic initiates who had abandoned the Mithraea at Housesteads, Rudchester, or one of the other possible locations for Mithraea along Hadrian's Wall.

${ }^{96}$ Shepherd 1998, 166-74. On the Mother Goddess statue at Carrawburgh, supra. n. 28.
} 
provided less of a financial burden on dwindling garrisons with less money to spend. However, the small size of Mithraea also enhanced the commitment of the cult's members and, consequently, their willingness to support the repair of their temples. Because of the limitations of space, the size of Mithraic congregations (which were male only) had to be capped, and an inscription from Virunum in Noricum records a Mithraic congregation being divided in half when it reached a hundred members. ${ }^{97}$ This limitation is why multiple Mithraea were active at the same time at the same locations. As sociological studies have demonstrated, such circumstances, in which congregations are kept relatively small, generate a particularly high level of commitment among the congregation members, as the small size allows them to build social bonds with a significant percentage of their fellow worshippers, unlike in congregations numbering in the hundreds or thousands. ${ }^{98}$ Furthermore, one's commitment to a group can be enhanced by repetitive participation in ritual activities, especially initiations. ${ }^{99}$ A prospective Mithraic initiate would need to have complete faith in his fellow Mithras worshippers, as he would be stripped naked, bound, and have perhaps a sword, a bow and arrow, or a torch waved in front of his face. ${ }^{100}$ Prospective members would be completely at the mercy of the congregation and could only pass the initiation by placing their trust in those around them. Particularly in a military community, membership in a Mithraic congregation provided another social bond among soldiers who already spent much time eating, sleeping, training, and fighting beside one another. It is not difficult to see how a group of soldiers who attended a local Mithraeum might band together to pay for its refurbishment while their enthusiasm to support other religious buildings waned.

Another reason Mithraea are preserved is the unique relationship between these structures and Mithraic ritual practices. While other so-called mystery cults, such as those of Isis and Sarapis and Magna Mater, held public festivals, processions, and feasts, ${ }^{101}$ this

\footnotetext{
${ }^{97}$ AÉpigr 1993, no. 1246 = AÉpigr 1994, no. 1334 = AÉpigr 1996, no. 1189 = AÉpigr 1998, no. 1016.

${ }^{98}$ For a review of the sociological studies, see Stark and Finke 2000, 154-62.

${ }^{99}$ Iannacone 1994, 1188.

${ }^{100}$ Clauss 2000, 102-5; Walsh 2018a, 10.

${ }^{101}$ Bowden 2010, 94-95, 165.
}
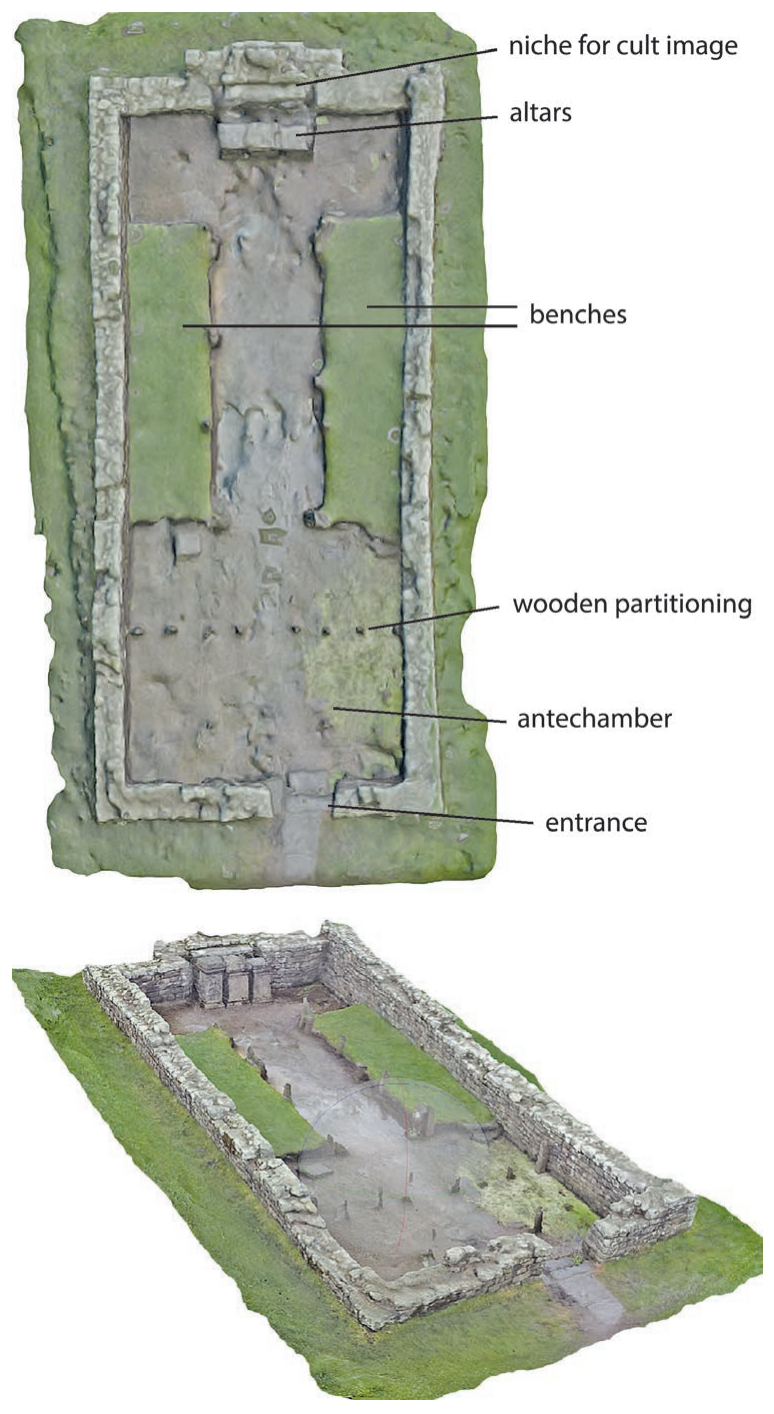

FIG. 17. Layout of a Mithraeum, with the Carrawburgh Mithraeum as a template. The temple is ca. $11 \mathrm{~m}$ in length. Two views of 3D computer model created from photographs.

was never the case for the cult of Mithras; all Mithraic rituals were held behind closed doors inside the Mithraeum, a space specifically designed to facilitate Mithraic rituals. As Beck has argued, the layout of the Mithraeum was intended to replicate not only the setting for the cult's central scene (the cave in which Mithras slew the bull) but also a microcosm of the cosmos. Drawing on the writings of the third-century philosopher Porphyry, who discussed the symbolism of the Mithraic cave in his On the Cave of the Nymphs, and on extant frescoes in the Mithraeum of Seven Spheres in Ostia, Beck postulates that a Mithraeum contained specific points relating to the equinoxes, the 
solstices, and the planets. Thus, movement through the Mithraeum represented movement across the cosmos. ${ }^{102}$ Beck has argued that a vessel found at Mainz that depicts Mithraic rituals bears an image of a Mithraic procession in which the second highest grade, the heliodromus (Runner of the Sun), walks across the Mithraeum to portray the movement of the sun across the equator. Moreover, Beck has illustrated that the design of the Mithraeum was essential in facilitating the most important Mithraic ritual: initiation. The initiation ceremony symbolized the descent and return of the initiate's soul through the cosmos, a journey that included passing through the various celestial gates marked out by the iconography of the Mithraeum. While other cults could continue to conduct at least some of their rituals without temples, this was not possible for the cult of Mithras, for the space created by the Mithraeum and the rituals conducted in this space were deeply intertwined. For the cult to continue, Mithraea had to be maintained, and that is what we see in the archaeological evidence. Indeed, it is striking that in some locations, such as Poetovio and Aquincum, when the civilian towns had been largely abandoned toward the end of the fourth century, Mithraea in these locations were still being used, an indication that people were making a journey to these particular spaces, perhaps across a considerable distance. The form of the rituals conducted in these Mithraea had changed by this time, with considerable numbers of coins now deposited in them as offerings, but these spaces clearly retained a special importance for people that other neighboring structures, religious or secular, did not. ${ }^{103}$

Concerning the cult of Jupiter Dolichenus, our information is less abundant. The cult does not seem to have garnered as great a following as that of Mithras. The possible pillaging and destruction of Dolichena along the Rhine and Danube under Maximinus Thrax, coupled with the destruction of the central temple at Doliche by the Sassanians in the 250s CE, also appears to have dealt the cult a considerable blow. ${ }^{104}$ Yet, the cult clearly retained the support of certain groups of soldiers into the late third century and beyond, for Dolichena were built and repaired on Hadrian's Wall and possibly at Gorsium. The reasons for this were likely to have been similar to those behind the survival of Mithraea, for the cults shared various aspects. As in the cult of Mithras, it was necessary to undergo an initiation in order to join the cult of Jupiter Dolichenus. After this rite, the initiates took part in ritual feasts. Both the initiation and the feasts took place behind closed doors inside the Dolichenum. Adherents of the Jupiter Dolichenus cult referred to each other as fratres (brothers), and the cult may have included a hierarchy akin to that of the Mithras cult. Inscriptions refer to noninitiated adherents of Jupiter Dolichenus as colitores (worshippers), candidates to be initiated are called candidati, and there are references to sacerdoti (priests) and patrēs candidatorum (fathers of the candidates). ${ }^{105}$ With secret initiations and feasts bonding together soldiers who referred to each other as brothers, the survival of Dolichena as well as Mithraea in the frontier zones is understandable. Apparently, however, there were certain differences between the cults. Unlike in the Mithras cult, it appears that women could be attached to the Dolichenus cult, but seemingly only as colitores, suggesting that initiations, as in the cult of Mithras, were limited to men only. ${ }^{106}$ Dolichena lack the uniform plan of Mithraea, perhaps an indication that there was not the close relationship between space and ritual in the cult of Jupiter Dolichenus that was evident in the Mithras cult. Like Mithraea, at least some Dolichena contained one or more benches on which members could recline while partaking in feasts, but the placement of extant benches is not uniform, and, in many cases, Dolichena have failed to produce evidence for such fittings. Some Dolichena are rectangular, while others are square, and one example in Moesia Superior is circular, suggesting a notable degree in variation among communities. ${ }^{107}$ These differences may explain why the cult of Jupiter Dolichenus, despite its longevity in some locations, did not achieve a level of popularity akin to that of the Mithras cult, but shared enough traits with the latter to see its temples maintained while other types fell into disrepair.

\footnotetext{
${ }^{102}$ Beck 2000, 2006.

${ }^{103}$ Walsh 2018a, 32-33.

${ }^{104}$ Tóth 1973.
} 


\section{CONCLUSION}

In Britain and Pannonia, support for temples in military communities follows a similar trajectory. From the reign of Nerva to that of Septimius Severus, an increasing number of temples exhibit investment by members of the military community in both provinces, but there is a marked decline in this investment in both regions from the Severan to the Tetrarchic period. During the Severan period, mainly under Severus himself, a significant amount of building work was conducted on temples in both areas, with Mithraea and Dolichena attracting particular attention. Such activities decreased significantly, however, following the death of Severus, even when some sites were restored and new military installations were constructed. Particularly in the case of Britain, there is a striking contrast between the declining fortunes of temples that neighbored forts and the significant number of temples still being built and repaired in other areas into the fourth century, especially in rural contexts. This contrast suggests that temples were valued more among the civilian population, or at least the villa-owning elite, than among their military counterparts.

There is a range of possible reasons why this decline occurred. First, since Severus himself was clearly interested in temple building, the significant amount of time spent by this emperor in Pannonia and then in Britain provided soldiers with the impetus to invest in temples. However, the subsequent Severan emperors, and the long list of short-lived emperors that succeeded them, did not (or could not) play such an active role in supporting the construction and repair of temples, and there was consequently less incentive for soldiers to do so. Second, among rank-and-file soldiers, it was increasingly harder to pay for the construction or repair of buildings when the value of a soldier's pay was significantly reduced and the smaller size of garrisons made group efforts to fund building projects more difficult. Although commanding officers probably still had the means to invest in such projects, they chose not to do so, possibly because of the general decline in public munificence during the third century. Third, the central rituals of the army (sacrifices, oaths, and festivals) never required a temple, thus such structures were not intrinsic to the religious behavior expected of members of the military community.

In contrast to this wider pattern of decline, temples to Mithras and Jupiter Dolichenus were still being built and repaired in both regions into the early fourth cen- tury. This can be explained in part by the small size of these temples, which made them less costly than larger temples. In the case of the Mithras cult, its organization, which fostered a significant level of commitment among its members, generated continuing support for the construction and repair of Mithraea. Because the specific building design of Mithraea was integral to Mithraic rituals, maintenance of these temples was imperative for the cult. In this respect, the Mithras cult differed from other religious groups, even other initiatory cults, which had significant public dimensions to their worship and could conduct at least some of their rituals out in the open. It is less clear why the cult of Jupiter Dolichenus persevered, but the attributes it shared with the cult of Mithras may have contributed to its survival. In essence, it was the uniqueness of these cults, focusing inward rather than outward, that helped their temples survive and be used into the fourth century. The continuing popularity this inward focus generated for such cults among the soldiers was what drove the Tetrarchs to restore a Mithraeum at Carnuntum (and perhaps to include a Dolichenum in their reconstruction of Gorsium) in contrast to their usual indifference toward temple construction and repair. As military men themselves, the Tetrarchs recognized how such cults supported the established social order with their systems of hierarchical grades. Indeed, one can see the influence of the army more generally in the religious iconography of the Tetrarchs, with its emphasis on ritual, particularly sacrifice, but little regard for temples.

Of course, this evidence only speaks for two provinces, though both were highly militarized. Future studies on temple patronage may reveal whether similar patterns are evident in regions where soldiers were stationed in fewer numbers, such as in Egypt or Asia Minor, and allow for a more holistic understanding of the relationship between military communities and temples. Additionally, one hopes additional evidence for religious spaces constructed within forts will come to light and further illuminate the relationship between religious practices in military communities and the later installation of churches in some forts.

\section{David Walsh}

Classical and Archaeological Studies

School of European Culture and Languages

University of Kent

Canterbury CT2 7NF

United Kingdom

djw43@kent.ac.uk 


\section{Works Cited}

Allason-Jones, L., and B. McKay. 1985. Coventina's Well: A Shrine on Hadrian's Wall. Gloucester, England: Alan Sutton.

Beck, R. 2000. "Ritual, Myth, Doctrine, and Initiation in the Mysteries of Mithras: New Evidence from a Cult Vessel." JRS 90:145-80.

2006. The Religion of the Mithras Cult in the Roman Empire: Mysteries of the Unconquered Sun. Oxford: Oxford University Press.

Birley, A., and A.R. Birley. 2012. "A New Dolichenum, Inside the Third-Century Fort at Vindolanda." In Iuppiter Dolichenus: Vom Lokalkult zur Reichsreligion, edited by M. Blömer and E. Winter, 231-57. Tübingen: Mohr Siebeck.

Birley, A.R. 1988. Septimius Severus: The African Emperor. London: Routledge.

Birley, R. 2009. Vindolanda: A Roman Fort on Hadrian's Wall. Stroud, England: Amberley.

Blake, J. 2003. Vindolanda Research Reports 2003. Vol. 2, The Excavations of 2001-2002: The Romano-Celtic Temple. Bardon Mill, England: Vindolanda Trust.

Boatwright, M.T. 2000. Hadrian and the Cities of the Roman Empire. Princeton: Princeton University Press.

Boon, G.C. 1960. "A Temple of Mithras at CaernarvonSegontium.” Archaeologia Cambrensis 109:136-78.

Boschung, D. 2012. "The Reliefs: Representation of Marcus Aurelius' Deeds." In A Companion to Marcus Aurelius, edited by M. van Ackeren, 305-14. Chichester, England: Wiley-Blackwell.

Bowden, H. 2010. Mystery Cults in the Ancient World. London: Thames and Hudson.

Breeze, D. 2018. Maryport: A Roman Fort and Its Community. Oxford: Archaeopress.

Brickstock, R.J. 2010. "Coins and the Frontier Troops in the 4th Century." In Finds from the Frontier: Material Culture in the 4th to 5th Centuries, edited by R. Collins and L. Allason-Jones, 86-91. York: Council for British Archaeology.

Brown, P. 1971. “The Church at Richborough.” Britannia 2:225-31.

Bryan J., R.S. Cubitt, J. Hill, N. Holder, S. Jackson, and S. Watson. 2017. Archaeology at Bloomberg. London: Museum of London Archaeology.

Bushe-Fox, J.P. 1932. Third Report on the Excavations of the Roman Fort at Richborough, Kent. London: Society for Antiquaries.

Christie, N. 2011. The Fall of the Western Roman Empire: An Archaeological and Historical Perspective. London: Bloomsbury.

Clauss, M. 2000. The Roman Cult of Mithras: The God and His Mysteries. Edinburgh: Edinburgh University Press.

Collingwood, R.G., and R.P. Wright. 1965. The Roman Inscriptions of Britain. Vol. 1, Inscriptions on Stone. Oxford: Clarendon.

Collins, R. 2012. Hadrian's Wall and the End of Empire: The Roman Frontier in the 4th and 5th Centuries. London: Routledge.
Cool, H.E.M. 2008. Roman Piercebridge: Overview. https://archaeologydataservice.ac.uk/archives/view/ piercebridge_eh_2008/overview.cfm.

Cool, H.E.M., and D.J.P. Mason. 2008. Roman Piercebridge: Excavations by D.W. Harding and Peter Scott 1969-1981. Durham, England: Architectural and Archaeological Society of Durham and Northumberland.

Daniels, C.M. 1980. "Excavation at Wallsend and the Fourth Century Barracks at Hadrian's Wall.” In Roman Frontier Studies 1979, edited by W.S. Hanson and L.J.F. Keppie, 173-200. BAR-IS 71. Oxford: British Archaeological Reports.

Drinkwater, J.F. 1987. The Gallic Empire: Separatism and Continuity in the North-Western Provinces of the Roman Empire A.D. 260-274. Stuttgart: Franz Steiner.

Eschbaumer P., V. Gassner, S. Jilek, M. Kandler, G. Kremer, M. Pfisterer, S. Radbauer, and H. Winter. 2003. "Der Kultbezirk des Iuppiter Optimus Maximus Heliopolitanus in den östlichen Canabae von Carnuntum." Carnuntum Jahrbuch:117-67.

Faulkner, N. 2000. The Decline and Fall of Roman Britain. Stroud, England: Tempus.

Fedak, J. 1991 "Excavations at Gorsium-Herculia, 19891990.” EchCl35(2):221-28.

Ferris, I. 2011. Vinovia: The Buried Roman City of Binchester in Northern England. Stroud, England: Amberley.

Fitz, J. 2004. “Gorsium.” In The Autonomous Towns of Noricum and Pannonia. Vol. 3, edited by M. Šašel-Kos and P. Scherrer, 197-207. Ljubljana, Slovenia: National Museum of Slovenia.

Fitz, J., and J. Fedak. 1993. "From Gorsium to Late-Antique Herculia: A Summary of Recent Work at Tác.” JRA 6:261-73.

Frakes, R.M. 2012. “The Dynasty of Constantine Down to 363." In The Cambridge Companion to the Age of Constantine, edited by N. Lenski, 91-107. Cambridge: Cambridge University Press.

Fulford, M. 1985. "Excavations on the Sites of the Amphitheatre and Forum-Basilica at Silchester, Hampshire: An Interim Report." AntJ 65:39-81.

Gillam, J.P., and I. MacIvor. 1954. "The Temple of Mithras at Rudchester." Archaeologia Aeliana 32:176-219.

Gordon, R. 1972. "Mithraism and Roman Society: Social Factors in the Explanation of Religious Change in the Roman Empire." Religion 2:92-121.

Hassall, M. 2017. Roman Britain: The Frontier Province. Collected Papers by Mark Hassall. Warminster, England: Hobnob.

Haynes, I. 1997. "Religion in the Roman Army: Unifying Aspects and Regional Trends.” In Römische Reichsreligion und Provinzialreligion, edited by H. Cancik and J. Rüpke, 113-26. Tubingen: Mohr Siebeck.

Haynes, I., and T. Wilmott. 2012. "The Maryport Altars: An Archaeological Myth Dispelled." Studia Universitatis BabesBolyai, Historia 57(1):25-37.

Hekster, O.J. 2000. “The City of Rome in Late Imperial Ideology: The Tetrarchs, Maxentius, and Constantine." Mediterraneo Antico 2(2):717-48. 
Hertz, P. 2002. "Sacrifice and Sacrificial Ceremonies of the Roman Imperial Army." In Sacrifice in Religious Experience, edited by A.I. Baumgarten, 81-100. Leiden: Brill.

Hodgson, N. 2009. Hadrian's Wall 1999-2009: A Summary of Recent Excavation and Research. Kendal, England: Cumberland and Westmorland Antiquarian and Archaeological Society.

Hoey, A.S., R.O. Fink, and W.F. Snyder. 1940. “The Feriale Duranum." YCS 7:1-222.

Holder, P. 2003. "Auxiliary Deployment in the Reign of Hadrian." BICS 46:101-45.

Hunter, F., M. Henig, E. Sauer, and J. Gooder. 2016. "Mithras in Scotland: A Mithraeum at Inveresk (East Lothian).” Britannia 47:119-68.

Iannacone L.R. 1994. "Why Strict Churches Are Strong." American Journal of Sociology 99:1180-211.

Irby-Massie, G. 1999. Military Religion in Roman Britain. Leiden: Brill.

James, S. 1999. "The Community of Soldiers: A Major Identity and Centre of Power in the Roman Empire." In TRAC 98: Proceedings of the Eighth Annual Theoretical Roman Archaeology Conference, Leicester 1998, edited by P. Baker, C. Forcey, S. Jundi, and R. Witcher, 14-25. Oxford: Oxbow.

Jobst, W. 1983. Provinzhauptstadt Carnuntum: Österreichs größte archäologische Landschaft. Vienna: Österreichischer Bundesverlag.

Jobst, W., and E. Weber. 1989. "Ein Heiligtum der Pferdegöttin Epona in Carnuntum(?)." ActaArchHung 41:349-58.

Johnson, A.C., P.R. Coleman-Norton, and F.C. Bourne. 1961. Ancient Roman Statutes: A Translation, with Introduction, Commentary, Glossary, and Index. Austin: University of Texas Press.

Jones, A.H.M. 1964. The Later Roman Empire, 284-602: A Social, Economic and Administrative Survey. Oxford: Blackwell.

Jouffroy, H. 1986. La Construction Publique en Italie et dans l'Afrique Romaine. Strasbourg: Association pour l'Étude de la Civilisation Romaine.

Kandler, M. 2004. “Carnuntum.” In The Autonomous Towns of Noricum and Pannonia. Vol. 3, edited by M. Šašel-Kos and P. Scherrer, 11-68. Ljubljana, Slovenia: National Museum of Slovenia.

Lavan, L. 2011. "The End of Temples: Towards a New Narrative?" In The Archaeology of Late Antique "Paganism," edited by L. Lavan and M. Mulryan, xv-lxv. Leiden: Brill.

Lavan, L., and M. Mulryan. 2011. The Archaeology of Late Antique "Paganism." Leiden: Brill.

Lewis, M.J. 1966. Temples in Roman Britain. Cambridge: Cambridge University Press.

Mattingly, D. 2006. An Imperial Possession: Britain in the Roman Empire, 54 BC-AD 409. London: Penguin.

Mócsy, A. 1974. Pannonia and Upper Moesia: A History of the Middle Danube Provinces of the Roman Empire. London: Routledge and Kegan Paul.

Mráv, Z. 2013. "Septimius Severus and the Cities of the Middle Danube." In Studia Epigraphica in Memoriam Géza Alföldy, edited by W. Eck, B. Fehér, and P. Kovács, 205340. Bonn: R. Habelt.
Mulvin, L. 2002. Late Roman Villas in the Danube-Balkan Region. Oxford: Archaeopress.

Osier, J. 1977. “The Emergence of Third-Century Equestrian Military Commanders." Latomus 36(3):674-87.

Osnabrügge, J. 2017. Epigraphische Datenbank Heidelberg. https://edh-www.adw.uni-heidelberg.de/edh/inschrift/ HD023078.

Pahl, J. 2010. “Der Kult des Jupiter Dolichenus-Ausbreitung, Selbstverständnis, Niedergang-Auf der Basis statistischer Erhebungen und mit einem ergänzenden Corpus." Ph.D. diss., University of Münster.

Pearson, A. 2002. The Roman Shore Forts: Coastal Defences of Southern Britain. Stroud, England: Tempus.

. 2003. The Construction of the Saxon Shore Forts. Oxford: Archaeopress.

Pekàry, T. 1986. “Das Opfer vor dem Kaiserbild.” BJb 186: 91-103.

Petts, D. 2016. “Christianity in Roman Britain." In The Oxford Handbook of Roman Britain, edited by M. Millett, L. Revell, and A. Moore, 660-81. Oxford: Oxford University Press.

Póczy, K. 1986. Aquincum: Das Römische Budapest. Mainz: Philipp von Zabern.

Poulter, A. 1992. "The Use and Abuse of Urbanism in the Danubian Provinces During the Later Roman Empire." In The City in Late Antiquity, edited by J. Rich, 109-45. London: Routledge.

Rees, R. 1993. "Images and Image: A Re-examination of Tetrarchic Iconography." GaR 40(2):181-200.

Richmond, I.A., and R.P. Wright. 1948. “Two Roman Shrines to Vintonus on Scargill Moor near Bowes.” Yorkshire Archaeological Journal 37:107-16.

Richmond, I.A., J.P. Gillam, and E. Birley. 1951."The Temple of Mithras at Carrawburgh." Archaeologia Aeliana 29:1-92.

Rogers, A. 2011. Late Roman Towns in Britain: Rethinking Change and Decline. Cambridge: Cambridge University Press.

Die römischen Inschriften Ungarns (RIU). 1972-2001. 6 vols. Edited by L. Barkóczi and A. Mócsy. Budapest and Bonn.

Rüpke, J. 2014. From Jupiter to Christ: On the History of Religion in the Roman Imperial Period. Oxford: Oxford University Press.

Rushworth, A. 2009. Housesteads Roman Fort: The Grandest Station. London: English Heritage.

Schwarzer, H. 2012. "Die Heiligtümer des Iuppiter Dolichenus." In Iuppiter Dolichenus: Vom Lokalkult zur Reichsreligion, edited by M. Blömer and E. Winter, 143-210. Tubingen: Mohr Siebeck.

Shepherd, J. 1998. The Temple of Mithras, London: Excavations by W.F. Grimes and A. Williams at the Walbrook. London: English Heritage.

Simpson, F.G., and I.A. Richmond. 1941. "The Roman Fort on Hadrian's Wall at Benwell." Archaeologia Aeliana 19:1-43.

Smith, A. 2001. The Differential Use of Constructed Sacred Space in Southern Britain, from the Late Iron Age to the 4th Century AD. Oxford: Archaeopress.

Southern, P. 2016. Hadrian's Wall: Everyday Life on the Frontier. Stroud, England: Amberley. 
Southern, P., and K. Dixon. 1996. The Late Roman Army. London: Batsford.

Speidel, M. 1992. “Roman Army Pay Scales.” JRS 82:87-106.

Srejović, D. 1993. Roman Imperial Towns and Palaces in Serbia. Belgrade: Serbian Academy of Sciences and Arts.

Stamper, J.W. 2005. The Architecture of Roman Temples: The Republic to the Middle Empire. Cambridge: Cambridge University Press.

Stark, R., and R. Finke. 2000. Acts of Faith: Explaining the Human Side of Religion. London: University of California Press.

Stiglitz, H., M. Kander, and W. Jobst. 1977. "Carnuntum.” Aufstieg und Niedergang der römischen Welt 2(6):581-730.

Tomlin, R.S.O., R.P. Wright, and M.W.C. Hassall. 2009. Roman Inscriptions of Britain. Vol. 3, Inscriptions on Stone (1955-2006). Oxford: Oxbow.

Tóth, I. 1973. "Destruction of the Sanctuaries of Iuppiter Dolichenus at the Rhine and in the Danube Region (235238)." ActaArchHung 25:109-16.

Vanderbilt, S. 2017. Roman Inscriptions of Britain. University of Oxford. https://romaninscriptionsofbritain.org/.

Vermaseren, M.J. 1956-1960. Corpus Inscriptionum et Monumentorum Religionis Mithriacae. 2 vols. Hagae Comitis (The Hague): M. Nijhoff.

Walsh, D. 2016a. "The Fate of Temples in Noricum and Pannonia." AJA 120(2):221-38.

2016b. "Understanding the Cult of Mithras in the Tetrarchic Period: A Socio-Archaeological Approach." In TRAC 2015: Proceedings of the Twenty-fifth Annual
Theoretical Roman Archaeology Conference, edited by M.J. Mandich, T.J. Derrick, S. Gonzalez Sanchez, G. Savani, and E. Zampieri, 141-52. Oxford: Oxbow.

2018a. The Cult of Mithras in Late Antiquity: Development, Decline and Demise. Leiden: Brill.

. 2018b. “The Butt Road 'Church,' Colchester, Reconsidered: Another Mithraeum?” Journal of Late Antiquity 11(2): 339-74

Ward-Perkins, B. 1984. From Classical Antiquity to the Middle Ages: Urban Public Building in Northern and Central Italy, $A D$ 300-850. Oxford: Oxford University Press.

Wilkes, J.J. 1993. Diocletian's Palace, Split: Residence of a Retired Roman Emperor. Sheffield, England: University of Sheffield.

Wilmott, T. 2001. Birdoswald Roman Fort: 1800 Years on Hadrian's Wall. Stroud, England: Tempus.

. 2010. "The Late Roman Frontier: A Structural Background." In Finds from the Frontier: Material Culture in the 4 th to 5 th Centuries, edited by R. Collins and L. AllasonJones, 10-16. York: Council for British Archaeology.

Wilson, A. 2007. "Urban Development in the Severan Empire." In Severan Culture, edited by S. Swain, S. Harrison, and J. Elsner, 290-326. Cambridge: Cambridge University Press.

Wolff, C. 2009. L'armée Romaine et la Religion sous le HautEmpire Romain: Actes du Quatrième Congrès de Lyon (2628 octobre 2006). Paris: Diffusion de Boccard.

Woods, D. 2017. “The Late Roman 'Camp Gate' Reverse Type and the Sidus Salutare.” NC 117:159-74. 